\title{
REFORMA DE LA COMPILACIÓN DE DERECHO CIVIL BALEAR Y CONSTITUCIÓN
}

\author{
Reform of the Compilation of Balear Civil Law \\ and Constitution
}

\author{
ANTONIA PANIZA FULLANA \\ Universidad de las Illes Balears \\ antonia.paniza@uib.es
}

Cómo citar/Citation

Paniza Fullana, A. (2019).

Reforma de la Compilación de Derecho Civil balear y Constitución.

Derecho Privado y Constitución, 34, 11-50.

doi: https://doi.org/10.18042/cepc/dpc.34.01

(Recepción: 05/01/2019; aceptación tras revisión: 10/06/2019; publicación: 26/06/2019)

\section{Resumen}

Este trabajo analiza los principales aspectos de la reforma de la Compilación balear llevada a cabo por la Ley 7/2017, de 3 de agosto. Esta norma pretende introducir en la Compilación medidas para salvaguardar la "protección del vínculo matrimonial» con un planteamiento del matrimonio como comunidad de vida, con deberes de ayuda mutua, capaz de modificar reglas clásicas del Derecho patrimonial en aras de la protección de intereses superiores. Para ello, este estudio parte de dos ejes principales: el primero, las medidas tendentes a la protección del cónyuge más desprotegido en el régimen económico de separación de bienes balear, y, el segundo, los problemas de derecho sucesorio, con especial mención al llamamiento a las instituciones de los territorios insulares en la sucesión ab intestato. Todo ello desde la perspectiva de la «conservación, modificación y desarrollo» del derecho civil propio.

\section{Palabras Clave}

Derecho Civil balear; régimen económico matrimonial de separación de bienes; vivienda familiar; compensación del trabajo para la familia; sucesión ab intestato. 


\begin{abstract}
This paper analyses the most important aspects of the reform of the Balearic Compilation carried out by Law 7/2017, of the 3rd of August. These changes are mainly intended to introduce measures to safeguard the "marriage bond" with the aim of ensuring it as an expression of a community of life, with duties of mutual assistance and capable of modifying the older property rights in order to protect higher interests. Specifically, this study is based on two main axes: the first, the measures aimed at the protection of the most unprotected spouse in the Balearic regime of separation of property and, the second, some problems about succession. In this case, the appeals to institutions of the island territories in the intestate succession, all this regulated by suppressing all the references to the Civil Code, aspect, the last, which has also raised several competence issues. All these questions will be studied from a constitutional perspective.
\end{abstract}

\title{
Keywords
}

Civil Law of Balearic Islands; financial marriage rules; separation of property regime; family house; household chores compensation; intestate succession. 


\section{SUMARIO}

I. INTRODUCCIÓN. II. COMPETENCIA EN MATERIA CIVIL DE LA COMUNIDAD AUTÓNOMA DE LAS ILLES BALEARS. III. LA REFORMA DE 2017 Y SUS RASGOS GENERALES. IV. COMUNIDAD DE VIDA Y SEPARACIÓN DE BIENES: ¿̇UNA PARADOJA?: 1. El trabajo para la familia y su compensación: una reforma esperada: 1.1. Planteamiento. 1.2. Presupuestos para obtener la compensación. 1.3. La compensación en las resoluciones de los tribunales. 1.4. En especial, la compensación en los contratos agrarios. 2. Disposición sobre la vivienda familiar: 2.1. Evolución de la cuestión. 2.2. Cesión del derecho patrimonial ante intereses superiores de necesaria protección. 2.3. El artículo 4.3 y su posible inconstitucionalidad. V. LOS PROBLEMAS DE DERECHO SUCESORIO: 1. La legítima de cónyuge separado de hecho. 2. La sucesión ab intestato: 2.1 Sobre la constitucionalidad de los artículos 53 y 84 de la Compilación. 2.2. Contenido y aplicación: algunas cuestiones. VI. A MODO DE CONCLUSIONES. BibLIOgRAFía.

\section{INTRODUCCIÓN}

En este trabajo se presentan algunos de los principales aspectos de la reforma de la Compilación de Derecho Civil balear de la Ley 7/2017, de 3 de agosto y se apuntan especialmente algunas cuestiones en relación con su constitucionalidad. El trabajo se centra en el análisis de dos ejes principales de la nueva norma. Por una parte, las medidas tendentes a la protección del cónyuge más desprotegido en un régimen económico de separación de bienes como el balear, y, por otra parte, algunos aspectos relacionados con la sucesión en el Derecho civil propio de las Illes Balears. Todo ello asentado sobre la doctrina del Tribunal Constitucional en relación con la «conservación, modificación y desarrollo» del derecho civil propio en las comunidades autónomas donde exista y un breve análisis comparado con el Derecho civil de otros territorios.

En el primer caso se estudiará la compensación del trabajo para la familia. Se trata de una cuestión no prevista en la Compilación hasta esta reforma, aunque sí reconocida por los tribunales por la vía de la aplicación analógica del art. 9 de la Ley de Parejas Estables de las Illes Balears (en adelante, LPEIB). También se analizará otra cuestión que da un giro al planteamiento inicial de un régimen de separación «absoluta» de bienes como el balear: la necesidad 
de consentimiento del cónyuge no titular para llevar a cabo actos de disposición sobre la vivienda familiar.

Por otra parte, el segundo bloque está dedicado al ámbito de la sucesión. Se destacan dos aspectos: el mantenimiento de los derechos legitimarios del cónyuge separado de hecho y los cambios en la sucesión ab intestato con la llamada, a falta de otros parientes, de los consejos insulares y ayuntamientos. Se modifica en este punto la regulación de la materia que hacía la Compilación con la remisión al Código Civil en este aspecto.

\section{COMPETENCIA EN MATERIA CIVIL DE LA COMUNIDAD AUTÓNOMA DE LAS ILLES BALEARS}

Un trabajo como el que se presenta requiere un análisis de la competencia de la comunidad autónoma en Derecho civil y su alcance; con ello, se podrá estudiar la reforma desde la perspectiva de su adecuación a la Constitución. De todos conocidas son las sentencias del Tribunal Constitucional con las que se ha ido detallando la doctrina sobre estas cuestiones. Ha sido en las sucesivas impugnaciones de leyes autonómicas con contenido de Derecho civil. También hay que decir que es un tema tratado ampliamente por la doctrina. Con ello se quiere dejar apuntado que no se pretende un estudio exhaustivo de la cuestión, sino más bien un planteamiento en el que asentar las bases de este estudio y el fundamento de algunas afirmaciones que se realizan a lo largo del mismo.

La competencia de las Illes Balears en materia de Derecho civil propio es indiscutida. En el marco del art. 149.1.8. ${ }^{a}$ de la Constitución española, el art. 30.27 del Estatuto de Autonomía de las Illes Balears establece la competencia de esta comunidad autónoma en Derecho civil. Concretamente,

[la] conservación, modificación y desarrollo del Derecho civil propio de las Illes Balears, incluida la determinación de su sistema de fuentes, excepto las reglas relativas a la aplicación y la eficacia de las normas jurídicas, las relaciones jurídico-civiles relativas a las formas del matrimonio, la ordenación de los registros y de los instrumentos públicos, las bases de las obligaciones contractuales, las normas para resolver los conflictos de leyes y la determinación de las fuentes del Derecho de competencia estatal.

Se trata de "conservar, modificar o desarrollar» las normas o las costumbres existentes en el momento de entrada en vigor de la Constitución.

En el caso balear, la posible inconstitucionalidad de algunos aspectos de la reforma no se fundamenta en la novedad de las figuras reguladas —aunque 
en el caso de la sucesión intestada parecía entenderlo así el Estado-, sino que está en los límites frente a otras competencias atribuidas al Estado ${ }^{1}$, como después se analizará. Con carácter general, los problemas de inconstitucionalidad por extralimitación en las competencias de las comunidades autónomas con Derecho civil propio se han ido planteando en relación con diferentes normas, lo que ha llevado a la interpretación por parte del Tribunal Constitucional de la expresión "conservación, modificación y desarrollo» del Derecho civil propio (García Rubio, 2017: 1-33). Como muestra, la STC 133/2017, de 16 de noviembre, y las SSTC 40/2018 y 41/2018, ampliamente analizadas por Egusquiza Balmaseda (2018: 47-48).

Por lo que se refiere a los límites de esta competencia en materia de Derecho civil propio se puede citar el caso de la Comunidad Valenciana ${ }^{2}$. Entre otras, la STC 82/2016, de 28 de abril, se refiere al contenido de la competencia en Derecho civil que entiende siempre vinculada a la "conservación, modificación y desarrollo del Derecho civil», que actúa como medida y límite a esta competencia y a la labor del legislador autonómico en esta materia. Doctrina reiterada en diferentes resoluciones: STC 88/1993, de 12 de mayo; STC 156/1993, de 6 de mayo; STC 31/2010, de 28 de junio, y 4/2014, de 16 de enero. En el caso valenciano se concluye que no ha quedado acreditada la exigencia del art. $149.1 .8,{ }^{\text {a }} \mathrm{CE}$ para que la comunidad autónoma de Valencia pueda legislar su propio régimen económico matrimonial. La cuestión que con ello se plantea es clara: ‘hasta dónde puede llegar el «desarrollo» del derecho civil propio? Según afirma el Tribunal Constitucional,

1 Como afirma el voto particular del magistrado don Juan Antonio Xiol Ríos a la STC $133 / 2017$, de 16 de noviembre, se distinguen tres reglas en relación con la competencia en Derecho civil: la legislación civil es competencia del Estado en aquellas comunidades autónomas que carezcan de Derecho civil propio; es competencia exclusiva de las comunidades autónomas con Derecho civil propio su conservación, modificación y desarrollo, y la regla de reserva final: ni siquiera las comunidades autónomas con derecho civil propio pueden regular sobre determinadas materias sobre las que tiene competencia exclusiva el Estado (las reglas relativas a la aplicación y eficacia de las normas jurídicas, relaciones jurídico-civiles relativas a las formas de matrimonio, ordenación de los registros e instrumentos públicos, bases de las obligaciones contractuales, normas para resolver los conflictos de leyes y la determinación de las fuentes del derecho).

2 Fueron leyes con sus respectivos recursos de inconstitucionalidad: Ley 10/2007, de 20 de marzo, de régimen económico matrimonial valenciano; Ley 5/2011, de 1 de abril, de relaciones familiares de los hijos e hijas cuyos progenitores no conviven, y Ley 5/2012, de 15 de octubre, de uniones de hecho formalizadas de la Comunidad Valenciana. Los problemas competenciales se plasmaron en la STC 156/2008, de 12 de junio, la STC 82/2016, de 28 de abril, y la STC 110/2016, de 9 de junio. 
en este caso, la competencia en materia civil en la Comunidad Valenciana tiene que referirse «al Derecho consuetudinario que, tras la abolición de los Fueros y hasta nuestros días, subsistiera en el territorio de la Comunidad Autónoma, siendo notoria la inexistencia de toda regla escrita que, antes de la Ley hoy impugnada, ordenara en dicho ámbito cualquier instituto civil de modo especial respecto al Derecho común». Y en el mismo sentido, la STC 110/2016, de 9 de junio, pone de manifiesto la ausencia de una institución consuetudinaria en Valencia que pueda servir de base para el «desarrollo» de la regulación de las uniones de hecho o del régimen económico matrimonial ${ }^{3}$. Sin embargo, también hay que citar el voto particular que contiene la STC 82/2016, de 28 de abril, que no encuentra impedimento en admitir el reconocimiento de un sistema de Derecho privado «foral» por parte del Estatuto de Autonomía, «aun cuando no estuviera vigente en el momento de la entrada en vigor de la Constitución, siempre que sea posible calificarlo como sistema de Derecho privado efectivamente vigente en el ámbito histórico, geográfico y sustantivo propio de los Derechos forales, como, sin que quepa duda razonable en términos historiográficos, es el caso del Derecho foral de Valencia ${ }^{4} »$.

Por otra parte, también se hace referencia a las materias conexas para la regulación de instituciones no preexistentes en el derecho civil propio, sobre las que la comunidad autónoma podría legislar siempre que se encontrara alguna conexión con otras figuras ya reguladas. La STC 156/1993, en relación con la Compilación de Derecho Civil balear, establece que el término «desarrollo" permite un crecimiento orgánico del derecho civil propio, dotándole de vitalidad hacia el futuro, por ello se permite la regulación de «instituciones conexas» con las ya reguladas en la Compilación, y ello dentro de una actualización o innovación de sus contenidos dentro de los principios informadores del Derecho civil, en este caso de las Illes Balears.

Este era el caso planteado en la STC 41/2018, de 16 de abril, en relación con el Derecho civil de Aragón, con el destino de las fincas procedentes de procesos de concentración parcelaria que carecieran de dueño conocido.

3 Realiza un análisis de estas sentencias y sus votos particulares De Verda y Beamonte (2017: 112-128). También, vid. Palao Gil (2017: 163-216) y Amat Llombart (2017: 8-11).

4 Según afirma el magistrado don Juan Antonio Xiol Ríos en el voto particular de la sentencia citada: «[...] el Derecho civil foral no puede ser concebido como una serie más o menos residual de normas e instituciones aisladas y asistemáticas sino como un sistema normativo dotado de la sistematización y conexión interna y de la completitud propias de un ordenamiento que tiene además constitucionalmente reconocida la posibilidad de determinar sus específicas fuentes de producción normativa». 
Se impugna por extralimitación de la competencia en Derecho civil. Según afirma la sentencia, las comunidades autónomas con Derecho civil propio no ostentan una competencia ilimitada sobre las materias civiles que no se reservan al Estado, pero podrán regularlas, incluso innovando, siempre con el requisito imprescindible de una conexión con el Derecho civil propio, "pues es la garantía de este ordenamiento jurídico y no otra cosa la ratio de la singularidad civil que se introduce en el primer inciso del artículo $149.1 .8^{\mathrm{a}} \mathrm{CE}$. En este caso, la sentencia sí encuentra conexión para regular la materia, sin embargo, el voto particular, suscrito por cinco magistrados, niega la conexión entre la atribución de los bienes inmuebles vacantes y la sucesión intestada a favor de la comunidad autónoma, ya que las considera instituciones con diferente naturaleza jurídica.

En la STC 95/2017, de 6 de julio, se discute si Cataluña tiene competencia para legislar sobre la propiedad temporal. Se busca la conexión con otras instituciones ya existentes, como la enfiteusis o la sustitución fideicomisaria, previamente reguladas por el Derecho civil catalán. Del análisis de la sentencia citada, Bercovitz Rodríguez-Cano se refiere al ámbito del «desarrollo» que permite el art. 149.1.8. ${ }^{\text {a }} \mathrm{CE}$. En sentido positivo, permite «una ordenación legislativa de ámbitos hasta entonces no normados por aquel Derecho", $y$, en sentido negativo, se trata de una competencia ligada necesariamente a la regulación de instituciones conexas con las ya reguladas en la Compilación «dentro de una actualización o innovación de los contenidos de ésta según los principios informadores peculiares del Derecho foral» (2018). Concretamente, al buscar esta conexión con figuras preexistentes, analiza la enfiteusis, que constituye un supuesto de propiedad dividida entre el dominio directo y el dominio útil. Se compara así con la propiedad temporal, en la que se diferencia el propietario actual y el sucesivo. Constituye entonces «una actualización a las necesidades presentes de acceso a la vivienda de un principio preexistente en el Derecho civil de Cataluña». La conexión a la que se refiere la sentencia tiene que ir referida al derecho civil propio en su conjunto, con los límites que la propia Constitución establece en el mismo artículo con las materias consideradas competencia exclusiva del Estado. En la STC 88/1993, impugnada la regulación del régimen de la filiación adoptiva en Aragón, se establece que aunque no se hubiera regulado la adopción en Aragón, sí existía conexión con la regulación del derecho de familia y sucesiones por causa de muerte.

Con este breve repaso de la doctrina del Tribunal Constitucional sobre la materia se está en condiciones de analizar la reforma del Derecho civil balear sobre los principios constitucionales existentes y dentro de los límites marcados por los mismos. 


\section{LA REFORMA DE 2017 Y SUS RASGOS GENERALES}

La Ley 7/2017, de 3 de agosto, por la que se modifica la Compilación de Derecho Civil balear, supone una reforma amplia de la Compilación si se compara con las que se habían aprobado hasta el momento. Se pretende presentar, con carácter general, el alcance de la reforma para, después, en los epígrafes que siguen, desarrollar y analizar algunos de los puntos más conflictivos por distintos aspectos.

Es al menos curioso advertir que esta reforma no ha dejado indiferente a nadie, por una parte, la doctrina se muestra crítica ante el nuevo texto normativo, y desde el Estado han llegado avisos de posible inconstitucionalidad. Sin embargo, en otras comunidades autónomas con Derecho civil propio parece que no se han planteado, a pesar de regular algunas cuestiones en el mismo sentido que la reforma de la ley balear; cuestión que, como se verá más adelante, no es óbice para plantear su constitucionalidad si se entiende que las circunstancias concurrentes pueden ser diferentes.

Son muchos los que están de acuerdo en que era necesaria una modificación y, seguramente, ampliación de la regulación del derecho civil propio de la Compilación balear dentro de lo establecido en el art. 149.1.8. ${ }^{\text {a }}$ CE y en el marco del art. 30.27 del Estatuto de Autonomía. Tal como afirma la exposición de motivos de la ley, se ha querido mejorar y ordenar sistemáticamente la regulación de las fuentes del Derecho civil balear, decantándose por la opción de mantener y desarrollar la compilación en lugar de lo que podría haber sido otra opción: la aprobación de leyes específicas y sectoriales fuera de ella —-debate que sigue abierto-. En este sentido, se había presentado un proyecto de Ley de Régimen Patrimonial del Matrimonio, elaborado por la Comisión Asesora de Derecho Civil Balear. Se pretendía regular con detalle el régimen económico del matrimonio, pero el texto nunca llegó a ver la luz. Sin embargo, afirma la exposición de motivos de la ley que con esta y otras mejoras se inaugura «una línea de trabajo constante, relativo a la ordenación y modernización respetuosa de las instituciones de la Compilación, para mantenerla y desarrollarla como corpus iuris de referencia del Derecho civil balear». La opción parece clara: el desarrollo del derecho civil propio dentro de la Compilación, manteniendo la actual estructura que regula los derechos de las diferentes islas en libros separados y regulación específica.

Por lo que se refiere al contenido de la reforma, de entrada, se ha querido mejorar y ordenar el art. 1. Ahora este artículo tiene un párrafo primero dedicado a la integración del derecho civil de las Illes Balears. Así como un segundo párrafo dedicado a las fuentes del derecho, que son la Compilación y las normas autonómicas que afecten a la materia de derecho civil, 
la costumbre y los principios generales de derecho civil propio. Y el punto tercero, que se refiere a las reglas de aplicación del Derecho civil de las Illes Balears: en primer lugar, la aplicación preferente de las normas de derecho civil propio; en segundo lugar, las disposiciones de cada uno de los libros - aplicables a las diferentes islas- se constituyen en el derecho común de las Illes Balears y se aplicarán supletoriamente a las demás leyes. La integración se realizará de acuerdo con los principios generales que informan el derecho civil balear. Siguiendo a Ferrer Vanrell, se ha querido dar a los principios generales del derecho una función de interpretación y autointegración del Derecho civil balear (2018: 17). En defecto de derecho civil propio, se aplicará como derecho supletorio el derecho civil estatal siempre que no sea contrario a los principios que lo informan y que el vacío no sea querido por el legislador balear en el marco de sus competencias 5 , cuestión que se plantea más adelante en este trabajo en relación con cuestiones concretas. Además, la jurisprudencia del Tribunal Superior de Justicia y, en su caso, la del Tribunal Supremo complementarán el ordenamiento civil balear ${ }^{6}$.

También anuncia la exposición de motivos que se han reordenado los artículos del régimen económico matrimonial en el libro de Mallorca, aunque se puede afirmar que la reforma ha ido más allá de una simple reordenación; reforma que será analizada en otro apartado de este trabajo. Afirma la exposición de motivos que hay que proteger la insolidaridad entre cónyuges, cuestión que podría estar en la misma naturaleza del régimen de separación de bienes que los cónyuges tienen en sus manos cambiar por otro.

5 En el caso catalán, afirma Arroyo Amayuelas, en relación con la aplicación supletoria del derecho estatal (art. 149.3 CE), que no significa que el ordenamiento jurídico autonómico sea insuficiente y necesite siempre del derecho estatal para suplir sus deficiencias. Entiende esta autora que el derecho supletorio no ha de aplicarse si una institución es desconocida en el ordenamiento jurídico de que se trate. No puede entenderse el art. 149.3 CE como una cláusula atributiva de competencias para legislar a favor del Estado con la intención de crear un derecho supletorio de las comunidades autónomas (vid. Arroyo Amayuelas, 2010: 168-169).

6 En relación con las modificaciones de este artículo, Jiménez Gallego afirma que se han separado las reglas referentes a la interpretación de las de la integración. En esta última se ha eliminado toda referencia a la tradición jurídica, apuntando ahora que se realizará de acuerdo con los principios generales que informan el Derecho civil balear. Entiende este autor que se hubiera podido aprovechar la reforma para derogar el art. 2 de la Compilación (vid. Jiménez Gallego, 2018a: 10-12). Ferrer Vanrell se muestra crítica con la literalidad del nuevo art. 1.1 de la Compilación de Derecho Civil balear, que lo ve como una «mala copia» del art. 111-1 del Codi Civil de Cataluña (vid. Ferrer Vanrell, 2018: 11). 
Se modifican otros artículos en los que se hacía necesaria una reforma como la adecuación de la legítima del cónyuge viudo al sistema de separación y divorcio no causal. El art. 45, antes de la reforma, establecía que el cónyuge que al morir su consorte no estuviera separado de hecho ni por sentencia firme sería legitimario en la sucesión de este «salvo que en ambos casos lo estuviere por causa imputable al difunto». Teniendo en cuenta la modificación de la separación y el divorcio en el Código Civil, tenía que desaparecer la mención a la causa. Sin embargo, la reforma ha ido más allá. Además de desaparecer la referencia a las causas, la separación de hecho deja de ser causa suficiente para la pérdida de los derechos legitimarios del cónyuge. Por otra parte, se regula la sucesión ab intestato, eliminando la remisión al Código Civil por lo que se refiere al llamamiento al Estado y da entrada a las diferentes instituciones insulares y los ayuntamientos como herederos ab intestato, cuestión que también ha planteado algún conflicto competencial. Sigue, sin embargo, sin ser legitimario el cónyuge viudo en el libro de Ibiza y se añade a las causas de indignidad para suceder los que no hayan prestado las atenciones debidas en concepto de alimentos en la sucesión de las personas con discapacidad.

Además, con la reforma, ya se pueden aplicar los pactos sucesorios - donaciones universales y definición - en Menorca, lo que hasta el momento no era posible; reforma aplaudida por los menorquines. Como novedad, en los contratos agrarios, como la sociedad rural menorquina, se otorga el derecho a una compensación económica a las personas casadas o unidas por análoga relación de afectividad que no tengan la titularidad compartida ni hayan recibido contraprestación por el trabajo realizado. En este caso, la ley remarca que se basa en la competencia de la comunidad autónoma en relación con las modalidades agrarias.

Por lo que se refiere a los derechos reales, a pesar de que se apuntaba la necesidad de «una revisión a fondo de los derechos reales contemplados en la Compilación de Derecho Civil, y muy especialmente por su repercusión social», la modificación se ha limitado a una reducción del $50 \%$ en concepto de laudemio en los alodios, que pasa del $1 \%$ al 0,5 \%, lejos de la «revisión a fondo» anunciada.

Por otra parte, se crea un nuevo órgano: el Consejo Asesor, que sustituye a la Comisión Asesora de Derecho Civil. Se trata de un órgano de consulta y asesoramiento en materia de Derecho civil de las Illes Balears?

7 Se regula en el Decreto 28/2018, de 7 de septiembre, por el que se regulan diversos aspectos del Consejo Asesor de Derecho Civil de las Illes Balears y se califica como «órgano permanente de consulta y asesoramiento del Gobierno y del Parlamento de 
Se introducen mejoras de redacción en varios artículos de la Compilación y se modifican otras leyes. Es el caso de la Ley 6/2001, de 11 de abril, del Patrimonio de la Comunidad Autónoma de las Illes Balears, consecuencia del nuevo papel de la Administración de la comunidad autónoma en la sucesión ab intestato. También hay que tener en cuenta la aplicación del derecho civil estatal por remisión estática que realiza la Compilación en su disposición final segunda. Las remisiones al Código Civil se entienden hechas al derecho vigente en el momento de aprobación de la Compilación o de las leyes de modificación, añadiendo la parte final del artículo en relación con las modificaciones posteriores a 1990 que «en las remisiones que estas hagan al Código Civil se entienden hechas a la redacción vigente a la entrada en vigor de cada ley de modificación».

Los avisos de inconstitucionalidad a la nueva norma del Parlamento balear han venido principalmente en dos puntos: la autorización del cónyuge no titular de la vivienda habitual para actos de disposición —en este caso, por su posible colisión con la Ley Concursal, invadiendo competencias mercantiles- y el nuevo régimen de la sucesión ab intestato, sustituyendo la anterior remisión al Código Civil y cambiando la sucesión del Estado, llamado en último lugar en defecto de otros parientes, por los Consejos Insulares y Ayuntamientos; temas que después serán analizados.

\section{COMUNIDAD DE VIDA Y SEPARACIÓN DE BIENES: ¿UNA PARADOJA?}

\section{EL TRABAJO PARA LA FAMILIA Y SU COMPENSACIÓN: UNA REFORMA ESPERADA}

\subsection{Planteamiento}

La exposición de motivos de la Ley 7/2017, de 3 de agosto, titula el apartado dedicado a la modificación del régimen económico matrimonial como «Protección del vínculo matrimonial de acuerdo a la doctrina constitucional y medidas para suavizar el sesgo de género en la regulación del régimen matrimonial de separación de bienes». A partir de esta frase se pueden plantear diferentes cuestiones. ¿Hay que suavizar el sesgo de género en la regulación del régimen económico matrimonial o ya existen en la práctica otros mecanismos

las Illes Balears, sin perjuicio de su función de asesorar también a los consejos insulares cuando éstos lo soliciten». 
para hacerlo? ¿Qué ocurre en aquellas parejas en las que hay igualdad en relación con el patrimonio? ¿Y en aquellos casos en que es la mujer la que cuenta con más bienes? Con ello solo se pretende poner de relieve que hay que analizar este tema desde la amplia tradición del régimen de separación de bienes en la sociedad mallorquina (y balear). Régimen que, en muchas ocasiones, ya ha encontrado otras fórmulas para compensar determinados aspectos provocados por la separación de patrimonios ${ }^{8}$.

Atendiendo a la doctrina constitucional a la que se hacía referencia, la STC 198/2012, de 6 de noviembre, se refiere al matrimonio como una institución que, tras una evidente evolución, se entiende como una "comunidad de afecto que genera un vínculo o sociedad de ayuda mutua entre dos personas que poseen idéntica posición en el seno de esta institución», y ello en el marco de un proyecto de vida familiar común. Tanto la compensación por el trabajo para la familia como la necesidad de consentimiento para la disposición de la vivienda habitual del cónyuge no titular se enmarcan en aquella protección; protección más a uno de los cónyuges que propiamente al vínculo matrimonial. La última medida mencionada podría chocar de entrada con un régimen de separación de bienes como el balear. Por otra parte, se mantienen los derechos legitimarios del cónyuge separado de hecho, con las consecuencias prácticas que ello puede conllevar para aquellas parejas que no hubieran formalizado una situación consolidada.

Prevalece la idea de comunidad sobre la de separación, por lo que los regímenes históricos de absoluta separación no encajan en esta doctrina, creando relaciones de «insolidaridad económica». Y ello puede ocurrir cuando uno de los cónyuges ha dedicado su tiempo y esfuerzo a la familia sin recibir ningún tipo de contraprestación, mientras que el otro ha podido progresar profesionalmente o incluso aumentar su patrimonio. Situación que, afirma la ley, fue ignorada por el legislador balear de 1990.

A la luz de las sentencias de los tribunales en la resolución de cuestiones relacionadas con la compensación, estaba claro que era necesaria una reforma en este sentido; de aquí su calificación en el título de este epígrafe como una «reforma esperada». Se hacía necesario introducir en la Compilación la compensación por el «trabajo para la familia» — a diferencia del Código Civil, que se refiere al «trabajo para la casa»—. Con ello se conseguía paliar la desigualdad producida en uno de los cónyuges por el «tiempo y dedicación no remunerada a la unidad familiar, al hogar, a la maternidad».

8 Señala Masot Miquel que en el régimen de separación de bienes balear es costumbre habitual que las adquisiciones onerosas realizadas constante matrimonio se adquieren conjuntamente por ambos cónyuges por mitades indivisas (2018). 


\subsection{Presupuestos para obtener la compensación}

El art. 4 de la Compilación de Derecho Civil balear anterior a la reforma se refería al levantamiento de las cargas del matrimonio y la necesaria contribución de ambos cónyuges en proporción a sus recursos económicos. Se entendía como contribución el trabajo para la familia. La nueva redacción del artículo añade que esta contribución podrá dar derecho a una compensación en determinadas circunstancias. Si no hubiera acuerdo, será el juez quien la establecerá.

A raíz de la reforma, el art. 4 se refiere expresamente al derecho a obtener una compensación que antes no existía. Se introduce así en la Compilación la doctrina de la STSJ de las Illes Balears de 24 de marzo de 2010, que establece la aplicación analógica del art. 9 LPEIB . En este sentido, afirma que lo que se pretende es evitar que el régimen de separación de bienes pueda amparar un enriquecimiento injusto producido por la desigualdad patrimonial. Ello supone el enriquecimiento de un cónyuge y el empobrecimiento del otro, a causa de una dedicación mayor al trabajo para la familia en el sentido de tiempo y dedicación no remunerada a la unidad familiar, al hogar o a la maternidad. ¿Se puede entender todo ello de la dicción literal del artículo («[...] se considera como contribución el trabajo para la familia y da derecho a obtener una compensación que el juez debe señalar, si no hay acuerdo cuando se extinga el régimen de separación»)?

Lo único que debe compensarse es la dedicación al trabajo para la familia, ya que el régimen de separación de bienes no es un régimen económico que pretenda la igualdad entre los cónyuges. Existen otros regímenes por los que podrían optar los cónyuges con independencia de su vecindad civil. Por otra parte, sí que hay que tener en cuenta que en las Illes Balears el régimen económico de separación de bienes se aplica, en primer lugar, en defecto de capitulaciones matrimoniales o espòlits en Ibiza. De la doctrina de la STSJ de las Illes Balears de 24 de marzo de 2010 ya citada se extrae:

- El texto del art. 4, antes de la reforma, no hacía ninguna referencia a la compensación. En el caso planteado en esta sentencia, se trata de establecer si cabe una compensación por el trabajo para la familia, a pesar de su falta de regulación en la Compilación. Afirma la sentencia que la compensación del art. 1438 CC, en sede del régimen de separación de bienes, ha provocado discrepancias en la doctrina: «[...] pues si algún autor aplaude la intervención de una idea comunitaria en el régimen de

9 Sobre esta sentencia, vid. Tur Faúndez (2011: 117-124). 
separación de bienes, otros la critican por introducir una regla anómala en el régimen de separación ya que se traduce en una corrección comunitaria impropia de tal régimen».

- El art. 9 de la LPEIB sí que prevé una "compensación económica» en caso de extinción en vida de la pareja estable. A partir de aquí el Tribunal se plantea si este artículo tiene fuerza expansiva, de tal modo que pueda aplicarse a los matrimonios, ante la falta de regulación de esta cuestión.

- Entiende el Tribunal que el cese de la convivencia matrimonial por separación, divorcio o nulidad equivale, como situación fáctica, a la extinción en vida de la pareja estable. Esta ruptura puede haber supuesto en ambos casos una «desigualdad patrimonial» que implique enriquecimiento injusto para uno de sus miembros y el consecuente empobrecimiento del otro. Además, en otros artículos de la LPEIB las equipara al matrimonio, argumento que sirve para reforzar la aplicación analógica a este caso. Concluye el Tribunal que de no optar por la aplicación analógica se «vulneraría la técnica integradora de la analogía legis e implicaría, necesariamente, una discriminación proscrita por el artículo 14 de la Constitución Española».

- Aceptada la aplicación analógica de la compensación prevista en la LPEIB, hay que decir que, para que pueda darse dicha compensación, se requiere el elemento objetivo de la «desigualdad patrimonial» entre los miembros de la pareja. Esta desigualdad será la determinante de un enriquecimiento injusto. Afirma el Tribunal que el causante de la desigualdad ha de ser una dedicación a la familia "cualificada», al haber permitido a uno de los cónyuges dedicarse a su trabajo fuera de ella y aumentar su patrimonio, mientras que el otro no haya podido conseguir este incremento por haber dedicado sus esfuerzos prioritariamente a la familia ${ }^{10}$. Todo ello debe quedar acreditado y tendrá que analizarse caso por caso, atendiendo a todas las circunstancias concurrentes.

La aplicación analógica que realiza el Tribunal Superior de Justicia de las Illes Balears de la LPEIB, fija — según afirma la Ley 7/2017, de 3 de agosto— un

$\overline{10}$ Afirma el Tribunal: «[...] de concurrir cualquiera de las causas típicas, solo se otorga compensación en el supuesto de empobrecimiento injusto del cónyuge que la reclama, lo cual evita la introducción, por vía indirecta, en nuestro Ordenamiento del régimen de participación en el que cada uno de los cónyuges adquiere el derecho a participar en las ganancias obtenidas por su consorte durante el tiempo que dicho régimen haya estado vigente (artículo $1411 \mathrm{CC}$ ), pues para obtener este resultado se ha de haber pactado expresamente (arts. 3, 64 y 67 CDCB)». 
«principio general del Derecho civil balear»: la prohibición de que el régimen de separación de bienes pueda amparar un enriquecimiento injusto producido por una dedicación mayor al trabajo para la familia.

El art. 9.2 de la LPEIB se refiere a la compensación económica, pero supedita la desigualdad patrimonial al enriquecimiento injusto. En cambio, el art. 4 de la Compilación tras la reforma solo se refiere a la posibilidad de obtener una compensación, sin establecer más presupuestos para ello ${ }^{11}$. A continuación, el art. 9.2 requiere que se haya dado alguno de los supuestos que enumera, que son que el conviviente haya contribuido económicamente o con su trabajo a la adquisición, conservación o mejora de cualquiera de los bienes comunes y privativos del otro miembro de la pareja y que el conviviente se haya dedicado con exclusividad o de forma principal a la realización del trabajo para la familia. ¿ Tienen los tribunales que seguir acudiendo a la analogía con la LPEIB a la hora de cuantificar la compensación o debe entenderse que puede darse con independencia de otras circunstancias? ¿Qué tipo de compensación? ¿Cuándo se puede obtener y cuáles son sus presupuestos? En todo caso, ¿es requisito imprescindible la existencia de desequilibrio patrimonial? ¿Es un derecho personalísimo que se extingue con la muerte del cónyuge acreedor?

Si bien el artículo no establece más presupuestos, de la exposición de motivos se extrae cuál es la finalidad de esta regla, remarcando además la introducción de la doctrina del Tribunal Superior de Justicia de las Illes Balears: evitar en el régimen de separación de bienes la desigualdad patrimonial que supone el enriquecimiento de uno y el empobrecimiento de otro ${ }^{12}$, atendiendo al tiempo y dedicación no remunerada a la familia, como ha quedado expuesto anteriormente.

\subsection{La compensación en las resoluciones de los tribunales}

Se pueden analizar algunos casos como el de la SAP de las Illes Balears de 14 de junio de 2018. Se había presentado demanda de divorcio y, con ella, toda la regulación por la que se regiría la pareja después de la ruptura. La sentencia del Juzgado de Primera Instancia establece, entre otros aspectos,

11 Afirma Verdera Izquierdo que la redacción del art. 4 de la Compilación se asemeja más al art. 1438 CC que al art. 9 de la LPEIB. En cambio, se regula esta cuestión con gran detalle en el art. 265-5 de la Propuesta de Código Civil elaborada por la Asociación de Profesores de Derecho Civil (2018: 36).

12 En relación con el enriquecimiento injusto como presupuesto de la compensación, vid. Bosch Capdevila (2010). 
una compensación económica a favor de la esposa de 100000 euros. Contra esta sentencia se interpone recurso de apelación. Uno de los motivos objeto de impugnación es precisamente la compensación económica atribuida a la esposa. Esta reconoce que quien ha contribuido principalmente al levantamiento de las cargas del matrimonio ha sido el esposo y que ella se ha ocupado del cuidado del hogar, la familia y los hijos, incluyendo el asesoramiento profesional a su marido. Es necesario un claro desequilibrio entre los cónyuges o los miembros de la pareja. En este caso concreto, la Audiencia no entiende que el trabajo para la familia realizado por la esposa suponga una "sobre aportación" que haya producido una pérdida de posibilidades de promoción profesional ni de incremento de su propio patrimonio. Además, en este caso, la vivienda familiar le pertenece proindiviso aunque el esposo canceló la hipoteca —aquí un ejemplo de las otras formas de compensación a las que se hacía referencia anteriormente-, también han quedado acreditadas las detracciones que ella hizo de la cuenta común. Concluye el Tribunal que, en este caso, no hay enriquecimiento injusto por parte del esposo. La sentencia ya se refiere a la nueva ley de modificación de la Compilación, aunque no estaba en vigor en el momento en que se presentó la demanda. Sin embargo, deja apuntado que a día de hoy no haría falta recurrir a la analogía en relación con el art. 9.2 LPEIB, ya que se ha introducido la compensación en el art. 4. La SAP de las Illes Balears de 28 de septiembre de 2018, refiriéndose al nuevo art. 4, establece que esta compensación no surge de manera automática; hay que contribuir a las cargas del matrimonio como una obligación propia de cada cónyuge. En este caso, la esposa carecía de patrimonio cuando se casó y tras la separación dispone de un patrimonio mayor que el de su marido, a pesar de haberse obtenido solo con los ingresos derivados de su trabajo.

Por su parte, la SAP de las Illes Balears de 14 de marzo de 2017 establece que la Compilación balear en su art. 4 —refiriéndose a su redacción antes de la reforma- no prevé ningún derecho de compensación. Entiende que no es aplicable el art. 1438 CC, ya que la Compilación optó por no prever este derecho en su momento. Sin embargo, recurre a la LPEIB — que, afirma, también es Derecho civil de las Illes Balears-y opta por su aplicación analógica en este caso, con los presupuestos que aquella ley establece ${ }^{13}$. Se extrae de la

13 Tienen que cumplirse los presupuestos del enriquecimiento injusto. La acreedora tenía que demostrar, como apunta la sentencia, que «[...] se ha dedicado con exclusividad o de forma principal a la realización del trabajo para la familia, sin que sea computable a tales efectos el simple "trabajo para la familia" al que se refiere el artículo 4.1 de la Compilación, que no es sino contribución obligatoria al levantamiento de las cargas del matrimonio, de forma que lo que da pie a la compensación económica no es 
sentencia citada que el simple trabajo para la familia no es suficiente para obtener la compensación, ya que cada cónyuge tiene que contribuir a las cargas del matrimonio.

Por su parte, la SAP de las Illes Balears de 7 de marzo de 2016 entiende que no hay enriquecimiento injusto y que el trabajo para la casa de la mujer ha sido compensado constante matrimonio: los inmuebles adquiridos constante matrimonio están inscritos a nombre de ambos esposos, a pesar del régimen de separación de bienes que rige el matrimonio y la falta de ingresos de la esposa. La SAP de las Illes Balears de 29 de enero de 2015 tampoco otorga compensación por el trabajo para la casa a la esposa, ya que, atendidas todas las circunstancias, no puede apreciarse un enriquecimiento injusto a favor del esposo y en perjuicio de la esposa.

Se puede plantear si haría falta una regulación del régimen económico matrimonial, dentro de la competencia que tiene atribuida la CAIB, en el marco del «desarrollo» de instituciones ya reguladas, que detallara, entre otras, la compensación por el trabajo para la familia (qué incluye, en qué casos y con qué presupuestos se puede dar, etc.) o bien dejar que sean los tribunales los que interpreten el precepto atendiendo a cada caso. A diferencia de las Illes Balears, en Cataluña se ha optado por una regulación pormenorizada de la cuestión. La compensación económica por razón de trabajo está regulada con detalle en el art. 232-5 del Codi Civil de Cataluña, estableciendo sus propias reglas de cálculo en el art. 232-6. En primer lugar, requiere que un cónyuge haya trabajado para la casa "sustancialmente» más que el otro y que al finalizar la convivencia el otro cónyuge haya obtenido un incremento patrimonial superior. Por otra parte, también tiene derecho a esta retribución cuando el cónyuge hubiera trabajado para el otro sin retribución o con una retribución insuficiente. Para su cálculo deben tenerse en cuenta la duración e intensidad de la dedicación, el que haya incluido crianza de hijos o cuidado de otros miembros de la familia que convivan con los cónyuges. También establece un límite: la cuarta parte de la diferencia entre los incrementos de los patrimonios, calculada de acuerdo con lo establecido en el art. 232-6, aunque si se prueba que ha sido superior, el juez podrá aumentar la cantidad de la compensación. En Cataluña, también se regula el caso de extinción del régimen económico-matrimonial por muerte — cuestión más problemática-. En este caso el cónyuge superviviente puede reclamar la compensación como derecho

el mero hecho de trabajar en la casa o para la familia, sino la producción de una desigualdad patrimonial, no corregida de alguna otra manera, subsistente al cese de la convivencia $[\ldots]$, por lo anteriormente dicho, implica empobrecimiento, aunque sea en el concepto de lucrum cesans». 
personalísimo condicionado a los bienes que le haya dejado en la sucesión voluntaria o los que le correspondan en la intestada y no cubran su importe ${ }^{14}$.

El Anteproyecto de Ley de Régimen Patrimonial del Matrimonio elaborado por la Comisión Asesora de Derecho Civil Balear regulaba con más detalle esta cuestión. El art. 9 definía el trabajo para la familia como «el trabajo para la casa, el cuidado y la atención de los miembros que convivan en el domicilio familiar y la colaboración no retribuida en la actividad empresarial o profesional del otro cónyuge». Además, en los apartados 3 y 4 de aquel precepto establecía el régimen de la compensación basado en incremento patrimonial y pérdida de oportunidades, calificándolo como un "crédito indemnizatorio ${ }^{15}$ ».

La Ley 10/2007, de Régimen Económico Matrimonial de la Comunidad Valenciana - declarada inconstitucional por falta de competencia sobre la materia- descarta el derecho a la compensación económica cuando el cónyuge acreedor haya obtenido ventajas patrimoniales equiparables a tal compensación y añade en su art. 14.2 que es compatible con otros derechos de carácter patrimonial y que tengan causa jurídica diferente. Y en su art. 12 incluye no solo el trabajo para la casa, sino también la colaboración no retributiva en la actividad empresarial o profesional del otro cónyuge.

En el ámbito del Código Civil, la STS de 14 de julio de 2011 establece que el trabajo para la casa constituye un «título para obtener una compensación en el momento de finalización del régimen». Cuando es de aplicación el art. 1438 CC, según el Tribunal Supremo, no es necesario para que uno de los cónyuges tenga derecho a la compensación que se haya producido un desequilibrio patrimonial por parte del otro cónyuge (entre otras, la STS de 26 de marzo de 2015 o la de 14 de abril de 2015). La otra cuestión que se plantea es si puede darse la compensación si se ha compatibilizado con un trabajo fuera del hogar o se ha

14 Bosch Capdevila (2010) comenta las cuestiones que se suscitaron con el texto anterior al no prever los supuestos de extinción por muerte. Se produjeron críticas en la doctrina ante el hecho de que habiéndose realizado un trabajo para la familia no remunerado, y, por tanto, un enriquecimiento injusto, no se tuviera derecho a la compensación. No podía tampoco sustentarse este hecho en que la persona viuda se viera recompensada con los derechos legitimarios, ya que no tenía por qué ser así. Finalmente, con el libro II del Codi Civil de Cataluña se incluye la compensación en caso de muerte del cónyuge.

15 Afirma: «Cuando el valor del trabajo hecho por uno de los cónyuges o el cómputo de la diferencia sea superior a lo que estaba obligado a llevar a cabo, tiene derecho al valor de este exceso. Este crédito indemnizatorio es compatible con la pensión compensatoria que prevé el ordenamiento del Estado pero que se deberán reclamar conjuntamente para que se puedan ponderar». Sobre esta cuestión, vid. Masot Miquel (2016: 731). 
tenido ayuda de otras personas en estas tareas. En relación con el trabajo fuera del hogar hay que citar la STS de 26 de abril de 2017. En ella se admite que la colaboración en actividades profesionales o negocios familiares en condiciones laborables precarias puede considerarse trabajo para la casa y da derecho a una compensación (Álvarez Olalla, 2017). En relación con esta sentencia, Moreno Flórez se plantea si la colaboración en negocios familiares realmente debe ser entendida como "trabajo para la casa», más teniendo en cuenta que se trata del régimen de separación de bienes, por lo que se refiere a los ingresos de cada cónyuge. También se muestra crítica esta autora con la idea de que solo pueda haber compensación en caso de que el trabajo se haya realizado en el ámbito familiar (Moreno Flórez, 2018: 271 y ss.).

En conclusión, el Tribunal Supremo, cuando aplica el art. 1438 CC, excluye la necesidad para obtener la compensación de que se haya producido un incremento patrimonial del otro cónyuge ${ }^{16}$. Como ya ha quedado establecido, en el caso de las Illes Balears, de una interpretación conjunta de la ley, parece desprenderse que la intención del legislador no fue esta.

\subsection{En especial, la compensación en los contratos agrarios}

Hay que situar la cuestión tratada en este epígrafe en el Libro de Menorca, concretamente en la figura de la sociedad rural menorquina. La Compilación se refiere en el art. 64, apartado tercero, primero al caso en el que el cultivador adopte la forma de titularidad compartida, y, segundo, al supuesto en el que no lo hiciera y el cónyuge hubiera trabajado en la explotación agraria sin ninguna remuneración, lo que le daría derecho a una compensación.

$\mathrm{El}$ art. 64 contiene una remisión expresa al derecho estatal. En este caso no al Código Civil, sino a la Ley 35/2011, de 4 de octubre, sobre titularidad compartida de explotaciones agrarias (concretamente a los arts. 2.2, 4, 5, 8 y 13). Se aplica cuando se adopta la forma de titularidad compartida de las explotaciones agrarias ${ }^{17}$ y cuando concurran las circunstancias del art. 13 de aquella Ley. En este último caso, en relación con el reconocimiento del derecho

16 Muestra su opinión contraria, entre otros, Álvarez Olalla al afirmar que el art. 1438 CC «no proclama un derecho autónomo a obtener dicha compensación, desvinculado de la regla de la proporcionalidad, tal y como lo ha entendido la jurisprudencia del Tribunal Supremo, sino que tiene por objeto disipar dudas en torno al hecho de que, aunque sólo se haya contribuido con trabajo en el hogar, ello puede dar derecho a la compensación oportuna, cuando el consorte no haya aportado lo que le correspondía, según la regla de la proporcionalidad» (2016). Además, vid. Berrocal Lanzarot (2017: 2618 y ss.).

17 Hay que mencionar que la Ley agraria de las Illes Balears aprobada el mes de febrero de 2019 se refiere en su art. 162 a la titularidad compartida. 
a la compensación económica en el supuesto de colaboración efectiva en la explotación agraria sin remuneración.

Esta compensación parte de la misma finalidad que la compensación por el trabajo para la familia: la realización de un trabajo que reporta algún beneficio para el otro cónyuge o miembro de la pareja sin ningún tipo de remuneración, lo que supone un empobrecimiento de uno de los cónyuges frente al enriquecimiento del otro. El fundamento en este caso es diferente. En el supuesto que ahora se plantea se cambian el fundamento y el ámbito competencial. No estamos en sede de régimen económico-matrimonial sino en contratos agrarios. Según la exposición de motivos de la Ley 7/2017: «[...] una novedad fruto del cambio de consciencia social en relación con el mundo rural y la necesidad de reconocer y visibilizar el papel invisible que el trabajo de las personas (tradicionalmente, la mujer) que, muchos años o toda una vida, conviven con el cultivador [...]», optando por una compensación económica cuando no se ha establecido la titularidad compartida ni se ha obtenido ningún tipo de remuneración a cambio del trabajo realizado ${ }^{18}$. Se trata de contratos agrarios, no de régimen económico matrimonial, aunque ambos se van a entrelazar necesariamente, por lo que hay que estar a la competencia de la CAIB que sustenta esta reforma.

Por ello, el ámbito de aplicación, según establece la propia ley de modificación, es más amplia: no es necesario que se trate de una pareja estable en el sentido de la ley que las regula en las Illes Balears, ya que no se trata de efectos de la convivencia, «sino de justicia social y laboral, ya que equivale a pagar por el trabajo realizado por parte de quien ha trabajado invisiblemente y sin derechos». De aquí se extrae el diferente fundamento de la compensación en uno y otro caso.

El supuesto de hecho para la obtención de la compensación parte de personas casadas o unidas por análoga relación de afectividad, que participen en la actividad de la explotación sin recibir ninguna remuneración a cambio ni estén en régimen de titularidad compartida. Se trata de un trabajo aportado a una explotación del otro cónyuge, sin haber obtenido nada a cambio. Hay que tener en cuenta que en el caso de separación de bienes las ganancias obtenidas con la explotación son del cónyuge titular de la misma.

Sin embargo, es inevitable poner en relación esta compensación con el régimen de separación de bienes. El art. 2.2 separa el régimen de titularidad

18 Martín Meléndez se refiere a la relación entre esta compensación y el régimen económico matrimonial, especialmente en el caso del régimen de separación de bienes, y también a su fundamento basado en un enriquecimiento injusto (2014: 531 y 577 596). 
compartida del régimen económico del matrimonio y del régimen sucesorio, y ello sin perjuicio de lo establecido en relación con la compensación. Aun así no dejan de ser interesantes los posibles puntos de fricción entre el régimen de separación de bienes y la titularidad compartida y la compensación. ¿Es un trabajo para la familia en el sentido ya estudiado? ¿Podría considerarse trabajo en un negocio familiar, en el sentido de algunas sentencias analizadas (colaboración no retribuida en la actividad empresarial o profesional del otro cónyuge)? En principio, no tiene la consideración de trabajo para la familia, sino que está trabajando en una explotación agraria del otro cónyuge o de su pareja, teniendo su régimen específico por lo que se refiere a la compensación.

El derecho a percibir esta compensación nacerá en casos de transmisión de la explotación agraria, de nulidad o disolución del matrimonio, por separación, nulidad o muerte o en supuestos de liquidación del régimen económico del matrimonio o de las relaciones patrimoniales de la pareja de hecho. ¿Cómo se conjuga el derecho a obtener compensación en caso de muerte en matrimonios regidos por el régimen económico matrimonial de separación de bienes? ¿Qué ocurre en el caso de compensación del trabajo para la familia? ¿Podrá el cónyuge superviviente exigir la compensación a los herederos? Este caso se ha previsto en Cataluña, pero no se ha dicho nada al respecto en la Compilación de las Illes Balears.

Por lo que se refiere al cálculo de la compensación, tendrá en cuenta el valor de la explotación, el tiempo efectivo y real de la colaboración y la valoración de dicha actividad en el mercado. El plazo para su reclamación prescribirá a los cinco años, tal como establece el art. 15 de la Ley sobre titularidad compartida de las explotaciones agrarias.

Con carácter general, es importante destacar que, con anterioridad a la reforma, tanto esta ley de 2011 de carácter estatal como la LPEIB, por lo que se refiere a las Illes Balears, ya preveían una compensación en situaciones que pudieran producir desigualdad económica entre los cónyuges o miembros de una pareja en determinadas circunstancias. Por otra parte, como se ha visto, fueron los tribunales los que ya en 2010 la aplicaron en los casos de ruptura matrimonial.

\section{DISPOSICIÓN SOBRE LA VIVIENDA FAMILIAR}

\subsection{Evolución de la cuestión}

La necesidad de consentimiento del cónyuge no titular para disponer de la vivienda familiar supone un cambio importante en la Compilación y en el régimen económico de separación de bienes de las Illes Balears. Régimen 
que siempre se había calificado como de «absoluta» separación, en el que los cónyuges ya articulaban en muchos casos otras medidas para salvar los posibles desequilibrios que podía producir, lo que se confirma con la práctica notarial en las islas. Como afirmaba la STSJ de las Illes Balears de 3 de septiembre de 1998: «Si no existe mención a la exigencia del consentimiento del cónyuge es porque el legislador decidió que esta era la mejor opción, habida cuenta que el régimen económico es el de absoluta separación de bienes». Ferrer Vanrell defiende la independencia de patrimonios y la falta de comunicación entre ellos, así como la total autonomía de gestión, administración y disposición de cada titular, y afirma que el Parlamento autonómico en la reforma de la Compilación de 1990 se manifestó en contra de introducir una norma de esta naturaleza (Ferrer Vanrell, 2001: 1107). Por el contrario, subyace en la presente modificación la idea reiterada de adecuar la protección del vínculo matrimonial a la doctrina constitucional que ya plantea la ley en su exposición de motivos.

Se planteó en su momento la posibilidad de aplicar el art. 1320 CC -que sí requiere este consentimiento- a supuestos en los que era de aplicación el Derecho civil balear. Ante esta situación se plantea la cuestión del carácter supletorio del derecho estatal y las lagunas realmente queridas por la Compilación. ¿Cuándo se aplica supletoriamente el Código Civil y cuándo se excluye esta posibilidad? ¿Tenía que aplicarse supletoriamente la previsión del art. 1320 CC o la propia Compilación había previsto no regular expresamente este punto, en un régimen de separación «absoluta» de bienes? Esta fue la cuestión planteada en la citada STSJ de las Illes Balears de 3 de septiembre de 1998. Tanto el Juzgado de Primera Instancia como la Audiencia Provincial consideraron aplicable el art. $1320 \mathrm{CC}$ al supuesto planteado, basándose principalmente en que este artículo del Código Civil es de aplicación al caso porque tiene que prevalecer la defensa constitucional de la vivienda y el interés familiar. Es el Tribunal Superior de Justicia de las Illes Balears el que casa la sentencia. Concluye que no existe laguna en la Compilación balear; en consecuencia, no puede aplicarse supletoriamente el Código Civil. De acuerdo con ello afirma que solo un cambio en la Compilación estableciendo una regla similar haría posible su aplicación. Por otra parte, se llegó a plantear la constitucionalidad de la ausencia de una regla como la del art. 1320 CC en la Compilación. En relación con esta cuestión, entiende la SAP de Baleares de 20 de septiembre de 2005 que la protección jurídica, económica y social de la familia puede darse de muchas maneras y no se impone una medida concreta. Concluye que ninguna sombra de inconstitucionalidad podía proyectarse sobre los arts. 3, 4 y 5 de la Compilación balear y de los artículos de la Constitución 
no se desprende la obligación de exigir el consentimiento de ambos cónyuges para disponer de la vivienda habitual ${ }^{19}$.

Se pueden analizar algunos antecedentes, la Comisión Asesora de Derecho Civil Balear, como ya se ha hecho referencia, presentó un Anteproyecto de Ley de Régimen Patrimonial del Matrimonio que pretendía regular de forma amplia sus relaciones económicas; texto normativo que nunca llegó a aprobarse. Se preveía en su art. 15 la necesidad de consentimiento del otro cónyuge para realizar actos de disposición, alienación o gravamen sobre la vivienda constituida como hogar familiar y su menaje, a pesar de que hubo otro texto de anteproyecto de ley que lo excluía ${ }^{20}$. Si el cónyuge no titular no diera su consentimiento podría darlo el juez en «interés de la familia». Ambas reglas tenían carácter imperativo. Por otra parte, también establecía que los notarios y registradores se abstendrían de inscribir los títulos en los que se dispusiera de la vivienda familiar sin consentimiento del otro cónyuge o de autorización judicial. El art. 17 se refería a la ineficacia de estos actos realizados sin el consentimiento preceptivo, que serían anulables. La acción caducaba a los cuatro años desde la inscripción en el Registro de la Propiedad o desde que el cónyuge hubiera conocido los actos de disposición sobre la vivienda.

La modificación ha llegado con la Ley 7/2017, de 3 de agosto, concretamente con el art. 4.3 - aplicable a Mallorca y Menorca- y el art. 67 —aplicable a Ibiza y Formentera—, que introduce expresamente la necesidad

19 Según la Sentencia citada: «[...] es patente, que, respecto a la llamada "vivienda familiar", el cónyuge no titular ostenta un simple "interés jurídicamente protegido" [recuérdese, al respecto, la doctrina del TC diferenciando los conceptos de "derecho" e "interés jurídicamente protegido"], cuya protección en base a los indicados principios constitucionales, implicaría el relegamiento y la preterición de otros valores e incluso "derechos" constitucionalmente protegidos, como es concretamente el derecho de propiedad (art. 33 C.E.) al que se haría objeto de una nueva limitación». También, vid. Ferrer Vanrell (2001: 1107 y ss.).

En relación con el art. 149.3 CE y la aplicación del derecho estatal como derecho supletorio afirma Arroyo Amayuelas que no presupone que el Derecho civil propio necesite siempre del derecho estatal para suplir las lagunas; este no puede aplicarse si se trata de una institución desconocida para ese ordenamiento ni en caso de autointegración de sus lagunas. Afirma la autora citada que el art. 149.3 CE no se puede entender como una cláusula atributiva de competencias para legislar a favor del Estado, con la intención de crear el derecho supletorio de las comunidades autónomas (vid. Arroyo Amayuelas, 2010: 168-169).

20 Comenta Masot Miquel que es interesante ver que hubo dos textos de anteproyecto de ley de régimen patrimonial del matrimonio, en uno se establece la necesidad de autorización y en el otro no (2018: 74). 
de consentimiento de los dos cónyuges o, en su caso, autorización judicial así como las consecuencias en caso de incumplimiento. Se reproduce en el caso de Ibiza en el art. 67, que establece que, en defecto de espòlits, el matrimonio se regirá por el régimen de separación de bienes. Sin embargo, hay voces discrepantes en relación con esta medida. Así, para el Derecho civil de Ibiza, Cardona Guasch no comparte la exigencia de consentimiento del cónyuge no titular porque considera que es una medida extraña a la libertad que siempre ha presidido las instituciones de esta isla ${ }^{21}$.

La introducción de este artículo supone un cambio —se puede reflexionar si necesario o no- en el régimen de separación de bienes balear. En relación con este tema, son varias las cuestiones que merecen ser estudiadas. La más grave, una posible inconstitucionalidad del artículo por vulneración de la competencia en legislación mercantil que corresponde al Estado. Por otra parte, se puede plantear, dado el tenor del artículo, si el legislador balear tiene competencia para establecer las consecuencias en caso de incumplimiento de la obligación que contiene esta norma, concretamente si podía establecer la anulabilidad del acto de disposición en el caso de que faltara la autorización preceptiva. Y también resulta interesante realizar un breve estudio de derecho interregional comparado estudiando las normas de otras comunidades autónomas que han regulado esta materia. Ya se puede adelantar que lo han hecho en el mismo sentido que la reforma de la ley balear.

\subsection{Cesión del derecho patrimonial ante intereses superiores de necesaria protección}

Las cuestiones se van sucediendo: ¿derecho patrimonial o régimen económico del matrimonio? Parece claro que es una norma de régimen económico matrimonial. ¿Afecta al derecho de propiedad? Claramente. ¿Acaso no se está limitando el poder de disposición sobre la cosa a quien legítimamente le corresponde? Así es. Algo parecido ha ocurrido con el derecho de uso de

21 Además, apunta esta autora que, aunque puede haber tantos argumentos a favor como en contra, hay que lamentar que la introducción de esta medida se haya hecho en contra de la opinión del Consejo Asesor de Derecho Civil de Ibiza, que, afirma, "siempre se ha manifestado abrumadoramente en contra de la adopción de esta medida» (Cardona Guasch, 2018: 184). Masot Miquel explica que el proyecto de modificación del año 1990 ya planteaba una modificación en el sentido de introducir la autorización del cónyuge no titular para actos de disposición, pero ante la fuerte oposición que se encontró al llegar al Parlamento se optó por desistir de la introducción de la medida (2018: 73-74). 
la vivienda familiar al cónyuge no titular en caso de separación y divorcio ${ }^{22}$, cuestión estudiada ampliamente por la doctrina. Se convierte en una carga difícil de articular con el derecho de propiedad. En ambos casos se alegan intereses superiores que requieren protección y justifican la limitación del derecho de propiedad, que en un sentido clásico no deberían darse. La calificación de un determinado inmueble como "vivienda familiar» es capaz de cambiar el propio contenido del derecho de propiedad en aras de salvaguardar un interés superior, el de la familia ${ }^{23}$. Como afirma Domínguez Martínez (2012), se ha configurado un régimen especial para la vivienda familiar como domicilio conyugal, con independencia de que haya hijos o no, que supone una limitación del contenido del derecho de propiedad.

¿A quién pretende proteger esta medida? No se trata de una modificación del régimen económico matrimonial en sí mismo considerado, sino de una medida de protección del otro cónyuge y de la vivienda familiar. Según la exposición de motivos de la Ley 7/2017, de 3 de agosto, la introducción de esta regla se justifica en la protección del cónyuge no titular ante actos de disposición de la vivienda familiar: «Es una mejora necesaria para proteger la unidad familiar ante las deudas del cónyuge titular único de la vivienda familiar ${ }^{24}$ ».

22 En Valencia, el art. 6.1 de la Ley 5/2011, de Relaciones Familiares de los hijos e hijas cuyos progenitores no conviven — declarada inconstitucional- preveía precisamente una compensación por pérdida del uso de la vivienda de la que es propietario, teniendo en cuenta las rentas por alquileres en viviendas similares en la misma zona y otras circunstancias concurrentes. Sobre esta cuestión, vid. De Verda y Beamonte (2017: 154-155).

23 Afirma la Resolución de la DGRN de 9 de octubre de 2018 en relación con la vivienda habitual y la obligación impuesta por el art. 1320 CC: «El citado artículo 1320 del Código Civil implica un límite a la libertad de disposición del cónyuge que es titular exclusivo de la vivienda familiar, cualquiera que haya sido el título de adquisición y el régimen económico matrimonial que rija en el matrimonio, que se justifica por la protección de los intereses familiares que la legislación considera superiores a los individuales de cada cónyuge [...]». Y la Resolución de la DGRN de 13 de junio de 2018 se refiere al art. 1320 CC como medida de protección de la vivienda familiar en situación de normalidad matrimonial. Apunta también que esta norma existe en otros derechos civiles de España, es el caso del art. 231-9 del Codi Civil de Cataluña y del art. 190 del Código del Derecho Foral de Aragón.

24 Afirma: «Es necesario, desde nuestra competencia, ofrecer mayor protección al cónyuge no titular porque, utilizando, en positivo, la idea de "connivencia" entre los cónyuges de la Ley concursal, podríamos entender que además de no tener titularidad formal de la vivienda familiar, el cónyuge no titular contribuye con su trabajo, remunerado o para la familia, a mantenerla y tiene que enterarse de los peligros financieros 
Hay que plantearse en este punto las consecuencias que estas afirmaciones tienen en un sistema de separación de bienes. Berrocal Lanzarot, en sede de Código Civil, afirma que la libertad de gestión, administración y disposición de los cónyuges en el régimen de separación de bienes tiene limitaciones en aras del interés familiar $(2017: 2607)$. Precisamente a ese interés, que requiere especial protección, se refiere la Resolución de la DGRN de 13 de junio de 2018. Afirma que, con la necesidad de consentimiento de ambos cónyuges, se salvaguarda el goce pacífico del inmueble en el que los cónyuges han fijado el alojamiento familiar. La función de tutela la sitúa claramente esta resolución en «la necesidad de asegurar al otro cónyuge y, a través de él, a la familia el espacio propio de convivencia frente a aquellos actos de disposición unilaterales que pudiera llevar a cabo el cónyuge propietario de la vivienda o titular de un derecho sobre ella, al que se impide cualquier actuación que pueda privar al consorte del uso compartido de este bien".

Los requisitos en los que se basa la aplicación de los arts. 4.3 y 67 de la Compilación son, por una parte, que se trate de actos de disposición, y que estos actos recaigan sobre la vivienda habitual y los muebles de uso ordinario de la familia (Munar Bernat, 2014: 223). La Resolución DGRN de 13 de junio de 2018 establece que el consentimiento requerido para el acto de disposición es exclusivamente el de los cónyuges, no interviniendo los hijos. También recalca que la aplicación de la medida opera cualquiera que sea el régimen económico aplicable al matrimonio. Costas Rodal (2009), refiriéndose al art. 1320 CC, afirma que, por lo que se refiere a la legitimación, no estarían legitimados los herederos, solo el cónyuge, pues con la muerte cesa la vivienda familiar.

Por otra parte, ¿puede el Derecho civil balear establecer las consecuencias en caso de incumplimiento? ¿Es posible que pueda determinar la falta de eficacia de estos actos? ¿No chocaría con la regulación de las bases de las obligaciones contractuales que corresponde al Estado? No ha habido pronunciamiento en relación con este tema. Hay que decir que las otras comunidades autónomas con Derecho civil propio también lo han incluido y que su regulación es idéntica a la del Código Civil ${ }^{25}$.

en los que puede estar incurriendo el cónyuge titular, que acabarán privando de hogar familiar a toda la unidad familiar».

25

En el ámbito del Código Civil, afirma Erdozáin López: «La jurisprudencia, fiel al tenor literal que expresan estos preceptos, es unánime al entender que, efectivamente, un acto de disposición sobre la vivienda habitual, realizado con independencia de lo dispuesto en el artículo 1320 CC, es anulable y no radicalmente nulo. [...] Por tanto, en lo relativo a las consecuencias de la declaración de nulidad de las obligaciones con- 
Finalmente, hay que dejar apuntado que el art. 5 LPEIB, dedicado al régimen económico de la pareja, remite a la aplicación supletoria del art. 4 de la Compilación de Derecho Civil balear, por lo que hay que entender que también sería aplicable la necesidad de consentimiento del cónyuge no titular en el caso de disponer de la vivienda familiar ${ }^{26}$.

\subsection{El artículo 4.3 y su posible inconstitucionalidad}

Además del comentario y análisis que merece este artículo en un sistema como el balear, se ha planteado su inconstitucionalidad por vulneración de normas mercantiles, por invasión de las competencias en Derecho mercantil, en relación con la Ley Concursal. Por nota remitida por la Dirección General de Relaciones con las Comunidades Autónomas, se plantean discrepancias de índole competencial en los dos primeros párrafos del nuevo art. 4 de la Compilación. Se plantea la posible contradicción de lo establecido en el art. 4.3 con el art. 6 del Código de Comercio y los arts. 77 y 78 de la Ley Concursal. Según este documento se estaría vulnerando la competencia exclusiva del Estado en materia mercantil del art. 149.1.6. ${ }^{\mathrm{a}} \mathrm{CE}$.

Lo que no se puede olvidar es que la modificación se presenta en el marco del régimen económico matrimonial, cuestión que claramente es competencia civil y regulada históricamente en la Compilación. Ante tales afirmaciones, se produce la colisión — si es que puede considerarse como tal — entre las dos normas: el art. 149.1.6. ${ }^{\mathrm{a}}$ y el 149.1.8. ${ }^{\mathrm{a}} \mathrm{CE}$; materia mercantil frente a la civil. Como apunta Llodrá Grimalt (2017a; 2018: 58-60), la nota remitida a la CAIB no tiene en cuenta la competencia autonómica sobre el Derecho civil propio del art. 149.1.8. ${ }^{\mathrm{a}} \mathrm{CE}$. Hay que establecer dónde se enmarca el artículo sobre la vivienda familiar. Parece claro que no es materia concursal, ni se está refiriendo a un cónyuge empresario, sino al régimen económico matrimonial de separación de bienes. Afirma la autora citada que los arts. 77 y 78 de la Ley Concursal son normas que afectan al deudor civil, por lo que si tuviera que afectar a alguna competencia estatal sería a la que se refiere a las «bases de las obligaciones contractuales».

Si se opta por el análisis desde otra perspectiva, la disposición final trigésima segunda de la Ley Concursal establece: «La presente Ley se dicta al

traídas, habrá que estar a lo dispuesto en los artículos 1303 y siguientes del Código Civil en lo que resulten aplicables» (2007).

26 Se decanta por esta aplicación Masot Miquel, quien además apunta que ya se había previsto en las leyes sobre parejas estables de otras comunidades autónomas (2018: $84)$. 
amparo de la competencia que corresponde al Estado conforme al artículo 149.1.6 y $8^{\mathrm{a}}$ de la Constitución", remarcando que ello es «sin perjuicio de las necesarias especialidades que en este orden se deriven de las particularidades del derecho sustantivo ${ }^{27}$ ». Parte de la doctrina considera que los arts. 77 y 78 de la Ley Concursal invaden competencias autonómicas en aquellos territorios con derecho civil propio.

Afirma Álvarez Olalla que si un cónyuge tiene bienes para hacer frente a sus deudas, «el legislador estatal no interfiere en las transacciones, gratuitas u onerosas que hayan tenido lugar respecto al otro cónyuge». Si interviniera en estos casos — afirma esta autora - sí que estaríamos ante un claro ejemplo de invasión de competencias en las comunidades autónomas con Derecho civil propio. Concluye que la incidencia de la Ley Concursal en las normas del régimen económico matrimonial del concursado en los derechos forales es mínima (Álvarez Olalla, 2010: $95-96$ y 105). Se podría entender la aplicación de la Ley Concursal como una norma especial en caso de insolvencia de uno de los cónyuges que desplazaría tanto la norma general del art. 1320 CC como la del art. 4.3 de la Compilación de Derecho Civil balear ${ }^{28}$.

También se muestra en contra de la inconstitucionalidad de esta norma Masot Miquel, quien además califica esta situación como agravio comparativo con otras comunidades autónomas que han regulado la cuestión de la misma forma, sin ser cuestionada su constitucionalidad. Muestra de ello es el caso de Cataluña, que regula esta cuestión en el art. 231-9 de su Codi Civil, bajo la rúbrica «disposición de la vivienda familiar». Hay que decir, como ya se ha comentado, que es aplicable cualquiera que sea el régimen económico matrimonial. Mientras que en Cataluña se refiere a los actos de enajenación, gravamen

27 Afirma Carlón Ruiz (2015): «El Derecho foral o especial de las Comunidades Autónomas, allí donde existe, no recoge, en efecto, una regulación general sobre los supuestos de insolvencia del deudor no comerciante. Sin embargo, en la regulación de ámbitos que les son propios — como, por ejemplo, el Derecho matrimonial—algunos Derechos forales recogen reglas con cierta incidencia en el régimen concursal. Así, en el caso vasco, el supuesto de cesación de la comunicación foral de bienes en caso de que el otro cónyuge haya sido declarado en quiebra o concurso de acreedores (art. 95 de la Ley 3/1992, de 1 de julio, de Derecho Civil foral vasco) y, en el caso navarro, el carácter de crédito preferente de las arras matrimoniales en caso de concurso, quiebra o ejecución de bienes del marido (art. 125 de la Ley 1/1973, de 1 de marzo, por la que se aprueba la Compilación de Derecho Civil foral de Navarra). Se trata, en todo caso — como no podía ser de otra manera-, de cuestiones meramente incidentales».

Así lo apunta Llodrá Grimalt (2017a: 13-14). 
o disposición en general de su derecho sobre la vivienda familiar o sobre los muebles de uso ordinario ${ }^{29}$, en la ley balear se refiere simplemente a la disposición de los derechos sobre la vivienda y los muebles de uso ordinario ${ }^{30}$.

En Aragón, el art. 109 del Decreto Legislativo 1/2011, de 22 de marzo, por el que se aprueba el Código del Derecho Foral de Aragón, en sede de efectos generales del matrimonio, se refiere a la necesidad de consentimiento del cónyuge no titular para actos de disposición «voluntaria» o sustracción del uso común de la vivienda habitual de la familia. En caso de enajenación se extingue el derecho expectante de viudedad. La consecuencia, como en los demás casos, es la anulabilidad, acción que pueden instar tanto el cónyuge como sus herederos, salvando también al tercero de buena fe. En el caso del País Vasco, es el art. 135 de La Ley 5/2015, de 25 de junio, de Derecho Civil Vasco, el que establece, en la comunicación foral, el consentimiento de ambos cónyuges para los actos de disposición de bienes; no se requiere este consentimiento para disponer del dinero, cuotas, aportaciones, cooperativas o partes representativas de la participación en sociedades, activos financieros o

29 A esta necesidad de consentimiento del cónyuge no titular en el derecho catalán se refiere la STSJ de Cataluña de 17 de diciembre de 2015: «La protección de la vivienda familiar, como elemento de soporte y estabilidad de la propia familia, empieza en el año 1981 cuando la Ley 11/1981, de 13 de mayo, introduce, entre otros, el art. 1320 en el Código Civil por el que se establece que para disponer de los derechos sobre la vivienda habitual y los muebles de uso ordinario de la familia, aunque tales derechos pertenezcan a uno sólo de los cónyuges, se requerirá el consentimiento de ambos o, en su caso, autorización judicial. [...]. Con la promulgación del Codi de Família por Llei 9/1998, de 15 de julio, quedó definitivamente configurado el principio por el también artículo 9, en forma detallada y completa. [...] El acto efectuado en contravención a esta exigencia de consentimiento o autorización es anulable a instancia del otro cónyuge o de los hijos menores que convivan en la vivienda en el término de cuatro años $[. .$.$] ».$

30 La SAP de Barcelona de 25 de julio de 2017 plantea un supuesto en el que es de aplicación el art. 231-9 en relación con la cuestión estudiada en un caso en el que el cónyuge titular de la vivienda constituye una hipoteca sobre la misma sin el consentimiento de su esposa. Concretamente tiene en cuenta el art. 569-31 del Codi Civil de Cataluña en relación con las hipotecas constituidas por un cónyuge sobre la vivienda familiar y la necesidad de consentimiento del otro cónyuge en estos casos. Al amparo de los artículos mencionados, la Audiencia reconoce la legitimación activa de la esposa, aunque no sea heredera de su marido, ni hubiera intervenido en la constitución de la hipoteca. Además, de acuerdo con los artículos del Codi Civil catalán citados, estima la acción de nulidad de la hipoteca y, en consecuencia, también de la ejecución hipotecaria. Destaca la falta de diligencia de la entidad bancaria al no determinar su carácter de vivienda habitual. 
valores mobiliarios $^{31}$. Y la Ley 81 del Proyecto de Ley Foral de Modificación y Actualización de la Compilación del Derecho Civil Foral de Navarra o Fuero Nuevo se refiere a la necesidad de autorización del cónyuge distinguiendo entre el consentimiento para disponer inter vivos o sustraer al uso común los derechos sobre la vivienda habitual o el mobiliario ordinario de la misma y el asentimiento en caso de que pertenezcan con carácter privativo a uno de los cónyuges.

\section{LOS PROBLEMAS DE DERECHO SUCESORIO}

\section{LA LEGÍTIMA DEL CÓNYUGE SEPARADO DE HECHO}

Una cuestión que con la reforma puede plantear problemas es el mantenimiento del derecho de legítima del cónyuge viudo en casos de separación de hecho. Afirma la exposición de motivos de la norma analizada que solo la ruptura del vínculo matrimonial debería provocar la extinción de los efectos post mortem del matrimonio ${ }^{32}$. Entiende que, de no hacerlo así, supondría una intromisión del legislador en la vida de los casados que no han formalizado su separación.

Según el art. 45 de la Compilación pervivirá el derecho de legítima en el caso que no esté separado legalmente y no se hayan iniciado los trámites establecidos en la legislación estatal por ninguno de los cónyuges ${ }^{33}$. Si no se

31 En Valencia, el art. 16 de la Ley de Régimen Económico Matrimonial, declarada inconstitucional, se refería también a la necesidad de este consentimiento en caso de disposición de la vivienda habitual o los muebles de uso ordinario. El art. 17 establecía la anulabilidad en caso de incumplimiento de lo establecido en el art. 16, remitiendo el régimen de caducidad al Código Civil. En el art. 18 se dejaba a salvo al tercero de buena fe en caso de anulabilidad.

32 Se afirma en la exposición de motivos de la ley: «Aunque, solo la ruptura del vínculo jurídico, que se produce con el divorcio, debería provocar el final de los efectos post mortem del matrimonio, ya que el matrimonio está vigente, y la legítima no se basa en la mera convivencia, sino en el vínculo jurídico válido, se ha decidido eliminar el efecto de pérdida de legítima solo en los casos donde la separación matrimonial es simplemente "de hecho"".

33 En este punto es interesante destacar que en el Proyecto de Ley de Modificación de la Compilación de Derecho Civil de les Illes Balears, publicado en el Boletín Oficial del Parlamento de las Illes Balears el 1 de julio de 2016, se mantenía la extinción del derecho de legítima ante la separación de hecho, siempre que se tratara de una verdadera separación basada en una clara ruptura de convivencia de la pareja. Como apunta la 
cumple esta doble condición, el cónyuge separado de hecho seguirá teniendo los derechos legitimarios que la Compilación otorga al cónyuge viudo. Por su parte, Llodrá Grimalt (2011), refiriéndose a las parejas estables, entiende que si no hay convivencia en el momento de fallecimiento no pueden otorgarse derechos sucesorios, ya que se ha suprimido uno de los elementos básicos de la pareja.

Se puede plantear en este punto el encaje del art. 13 LPEIB con la Compilación. Este artículo concede al conviviente que sobreviviera al miembro de la pareja premuerto los mismos derechos que la Compilación otorga al cónyuge viudo en la sucesión testada e intestada. No hay que olvidar que en Ibiza no existe legítima del cónyuge viudo. Hubiera sido un buen momento para armonizar el art. 13 LPEIB con la Compilación.

$\mathrm{Ni}$ la separación judicial ni la de hecho rompen el vínculo matrimonial y la judicial consolida la fáctica. La duda que aquí se puede plantear es cuál es el fundamento de la legítima del cónyuge viudo: ¿el vínculo jurídico o la convivencia? La STSJ de las Illes Balears de 27 de julio de 2009 se mostraba claramente partidaria de la convivencia como elemento determinante de los derechos sucesorios al cónyuge supérstite ${ }^{34}$. También se decantan por la posición contraria a la establecida en la reforma de la Compilación balear Galicia Aizpurua y Castellanos Cámara al entender que en un sistema basado en el

exposición de motivos del proyecto de ley, la legítima vidual se basa en la doctrina jurisprudencial fundamentada en la convivencia, lo que conlleva su pérdida cuando hay una separación de hecho.

Afirma esta sentencia: «La convivencia se halla además en la raíz de la atribución legal de derechos sucesorios al cónyuge supérstite. En medida mayor o menor pero siempre cierta, todo conviviente se beneficia de la posición económica del otro y participa del nivel de vida que a éste le ofrecen sus ingresos y patrimonio. También ocurre así, resulta notorio, en los regímenes matrimoniales de separación de bienes. [...]. El reconocimiento de legítima vidual — en el inicio histórico sólo a favor de la viuda — busca el objetivo de proporcionar al supérstite recursos con que atender a su subsistencia y preservar el nivel de vida de que disfrutó en compañía del premuerto. La legítima del cónyuge viudo también retribuye la mutua prestación cotidiana de apoyos y ayudas de toda índole, materiales o intangibles, consustancial a cualquier vida de pareja. Si, pues, no existe convivencia, el derecho de legítima queda sin justificación. La convivencia se encuentra asimismo en la base del derecho a detraer los bienes integrantes del ajuar doméstico que contempla el art. 3.3, párrafo segundo, de la Compilación y constituye presupuesto indispensable de los derechos que la Ley Balear 18/2001, de 19 de diciembre, de Parejas Estables, otorga al sobreviviente en caso de fallecimiento del otro». Sobre esta cuestión también puede tenerse en cuenta la SAP de las Illes Balears (Sección 5. ${ }^{\text {a }}$ de 12 de diciembre de 2016. 
consentimiento del vínculo matrimonial no tiene sentido mantener los derechos sucesorios cuando la voluntad manifestada en ese consentimiento ya no existe, aunque sea de manera fáctica (Galicia y Castellanos, 2018).

Por otra parte hay que resaltar la incoherencia que puede producirse en el texto legislativo en relación con la sucesión intestada. La Compilación en su art. 53 establece que la sucesión ab intestato se regirá por lo dispuesto en el Código Civil, dejando a salvo los derechos del cónyuge viudo del art. 45 y lo previsto en el art. 51 de la Compilación. Los llamamientos son los de los artículos 930 a 955 CC, a excepción de la sucesión a favor del Estado. Según el artículo $945 \mathrm{CC}$, en sede de sucesión del cónyuge, establece que no tendrá lugar este llamamiento si el cónyuge estuviere separado legalmente, pero también si lo estuviere de hecho ${ }^{35}$.

Esta regulación de la legítima del cónyuge viudo abre la puerta al planteamiento de dudas y reflexiones sobre la cuestión.

\section{LA SUCESIÓN AB INTESTATO}

\subsection{Sobre la constitucionalidad de los artículos 53 y 84 de la Compilación}

El art. 24 de la Ley 7/2017, de 3 de agosto, modifica el art. 53 aplicable a Mallorca y Menorca, y el art. 34 modifica, en el mismo sentido, el art. 84 para la sucesión intestada en Ibiza y Formentera. En el primero, según el primer apartado del art. 53, la sucesión ab intestato se remite al Código Civil, sin perjuicio de los derechos del cónyuge viudo que reconoce la propia Compilación. El cambio se produce en el apartado segundo, concretamente en la sucesión de los Consejos Insulares y ayuntamientos en lugar del Estado, a falta de los demás herederos llamados a la sucesión intestada. En el mismo sentido, el art. 84.3 de la Compilación de Derecho Civil balear en el libro III que contiene las disposiciones aplicables en las islas de Ibiza y Formentera ${ }^{36}$.

35 Manifiesta su opinión contraria Jiménez Gallego y hace notar la diferente regulación por lo que se refiere al derecho a legítima y los derechos sucesorios en la sucesión $a b$ intestato en caso de separación de hecho. El cónyuge viudo no hereda en caso de separación judicial ni de hecho (vid. Jiménez Gallego, 2018b: 105).

Podría plantearse como reflexión qué ocurriría ante una reclamación de legítima en una situación de separación de larga duración y muy consolidada sin que se hubiese llegado a formalizar, ¿podría considerarse una actuación en contra de los propios actos, y en consecuencia, contraria a la buena fe?

36 Se modifica en los mismos términos, aunque hay que tener en cuenta que la remisión del primer párrafo se realiza al Código Civil sin especialidades, ya que el libro de Ibiza no prevé legítima para el cónyuge viudo. 
La disposición adicional tercera de la Ley 7/2017, de 3 de agosto, añade dos nuevos artículos, el 41 bis y el 41 ter a la Ley 6/2001, de 11 de abril, del Patrimonio de la Comunidad Autónoma de las Illes Balears, en sede de sucesión intestada para adecuarlo a los cambios producidos en la Compilación. Según este artículo, corresponderá a la Administración autonómica efectuar la declaración de heredero intestado y el procedimiento administrativo aplicable tendrá que determinarse reglamentariamente.

En relación con esta modificación, se ha planteado una posible inconstitucionalidad de los arts. 53 y 84 de la Compilación por posible vulneración de la competencia estatal. Se recibió una nota de la Dirección General de Relaciones con las Comunidades Autónomas. En ella se hacía constar que la modificación en relación con la sucesión intestada en las Illes Balears podría invadir la competencia del Estado del art. 149.1.8. ${ }^{a} \mathrm{CE}$, ya que no se estaría desarrollando el Derecho civil propio, sino creando una norma nueva en materia de sucesión.

Antes de la reforma, la remisión al Código Civil hacía que, en defecto de los herederos previstos en la línea sucesoria, quien heredaba en último lugar era el Estado. Esta antigua remisión parece ser la causa que ahora vetaría un cambio en la sucesión intestada en el Derecho civil balear. En caso de ausencia de las personas indicadas en los arts. 930 a 955 CC, se completan los llamamientos con las Administraciones territoriales de la comunidad autónoma en lugar del Estado. Entiende en este caso el Estado que el hecho de que la Compilación previera una remisión al Código Civil hace que ahora no se pueda excluir (Llodrá Grimalt, 2018: 47). Son varias las cuestiones que pueden plantearse: la remisión realizada anteriormente, ¿veta todo cambio en la redacción del artículo o, aun más, en la regulación de la materia? Aun cuando se cambiara, ¿no estaríamos ante una materia competencia de la comunidad autónoma de las Illes Balears como es la sucesión? Según afirma la nota citada: «[...] la nueva regulación [...] no estaría desarrollando su derecho civil foral, sino que supondría el establecimiento de una norma nueva en materia de sucesión intestada para todo el territorio de la Comunidad Autónoma», lo que no tendría cabida en el art. 149.1.8 ${ }^{a} \mathrm{CE}$. ¿Puede cambiarse una remisión por una regulación propia o con ello se están invadiendo competencias estatales? ¿Se puede incluir tal cambio en la "conservación, modificación y desarrollo" del Derecho civil propio de las Illes Balears? ¿No estaríamos ante una «modificación» del Derecho civil balear?

La respuesta tendría que ser afirmativa. Así opina Llodrá Grimalt, quien entiende que este planteamiento de la constitucionalidad del precepto modificado vulneraría la doctrina jurisprudencial del Tribunal Constitucional, ya que se trata solo de una modificación de la norma, ni siquiera se está ante un 
desarrollo de la materia ${ }^{37}$. Muy claro se muestra Coca Payeras al referirse a esta cuestión: la sucesión intestada ya era objeto de regulación en la Compilación de Derecho Civil balear, «y el que lo fuera por remisión estática a las normas del Código civil, y más aún con ciertas reservas respecto del cónyuge viudo, evidencia que dicha "materia" forma parte del Derecho civil propio, por lo que creemos que en puridad las citadas normas no son ni deben ser declaradas inconstitucionales» (Coca Payeras, 2018). Galicia Aizpurua y Castellanos Cámara también son favorables a esta postura doctrinal. Entienden que, desde una perspectiva constitucional, no se le puede hacer ningún reproche a la modificación en materia de sucesión intestada, al tratarse de una «modificación» del Derecho civil propio, según lo establecido en el art. 149.1.8. ${ }^{a} \mathrm{CE}$. Afirman los autores citados que al tratarse de una materia ya regulada en el derecho balear vigente al promulgarse la Constitución, la comunidad autónoma puede regular sobre la materia en el sentido que estime oportuno en cada momento (Galicia y Castellanos, 2018).

De acuerdo con ello, parece que se estaría vetando cualquier regulación que desarrollara la sucesión intestada en las Illes Balears. De ser cierta esta afirmación iría incluso en contra de la doctrina del Tribunal Constitucional sobre el ámbito competencial de las comunidades autónomas con derecho civil propio. ¿¿No se podría desarrollar una materia sobre la que claramente las Illes Balears tienen competencia? ¿Quedaría petrificada la regulación de la materia sin posibilidad de cambio ni desarrollo? Es más, aun en el caso de que no se admitiera como modificación, todavía nos quedaría afrontar la cuestión de acuerdo con la regulación de materias conexas, con fundamento en la doctrina del Tribunal Constitucional ya comentada. Se refiere la STC 41/2018, de 26 de abril, a la vinculación de "desarrollo» con la garantía constitucional de "los "derechos civiles forales o especiales vigentes en ciertos territorios" y, más en concreto, con el reconocimiento constitucional de la vitalidad hacia el futuro de tales ordenamientos preconstitucionales ${ }^{38}$.

También es interesante tener en cuenta que otras comunidades autónomas con Derecho civil propio han regulado la sucesión ab intestato, y, lejos de remitir la cuestión al Código Civil, establecen el llamamiento, en último lugar, a favor de la comunidad autónoma correspondiente. Es verdad, como

37 Vid. Llodrá Grimalt, 2017b. Sobre este tema, vid. STC 31/2010, de 28 de junio, o STC 88/1993, de 12 de marzo.

38 En el mismo sentido, la STC 31/2010, de 28 de junio de 2010, añade: «Cabe, pues, que las CC.AA. dotadas de Derecho civil foral o especial regulen instituciones conexas con las ya reguladas en la Compilación dentro de una actualización o innovación de los contenidos de ésta según los principios informadores peculiares del Derecho foral». 
ya apunta Egusquiza Balmaseda (2018: 75), que la constitucionalidad de una determinada norma no debe fundamentarse en lo acaecido en otras comunidades autónomas, sin llevar a cabo un análisis del derecho civil propio, y Arroyo Amayuelas también se pronuncia en este sentido, planteando que el Tribunal Constitucional puede haberse pronunciado en unos casos pero no en otros, resultando penalizadas unas comunidades autónomas y no otras (2010).

La exposición de motivos del Proyecto de Ley de Modificación de la Compilación de Derecho Civil de las Illes Balears (2016) ya se refería expresamente a otras comunidades autónomas con derecho civil propio que habían regulado la cuestión. Es verdad que en aquel texto quien heredaba era la comunidad autónoma, no los Consejos Insulares, pero a los efectos de modificación de la Compilación y su validez la cuestión es la misma. Como ejemplo, citaba este texto los arts. 442-12 y 442-13 de la Ley 10/2008, de 10 de julio, del libro cuarto del Codi Civil de Cataluña ${ }^{39}$; el art. 117 de la Ley 5/2015, de 25 de junio, de Derecho Civil del País Vasco; los arts. 536 y 537 del Código de Derecho Foral de Aragón, aprobado por Decreto Legislativo 1/2011, de 22 de marzo ${ }^{40}$; los art. 267 a 269 de la Ley 2/2006, de 14 de junio, de Derecho Civil de Galicia, y el número 7 de la Ley 304 de la Compilación de Derecho Civil Foral o Fuero Nuevo de Navarra ${ }^{41}$. En este último caso, afirma la STC 40/2018 que, con posterioridad al Fuero Nuevo, Navarra tiene reconocida en la legislación foral civil preferencia en los llamamientos de herencias legales frente al Estado para apropiarse de los bienes mostrencos y en materia de sucesión intestada contempla los llamamientos a la Diputación Foral en defecto de parientes.

\subsection{Contenido y aplicación: algunas cuestiones}

Salvada su constitucionalidad, merece un comentario la regulación contenida en los arts. 53 y 84. Como antecedentes de este cambio en la sucesión intestada, hay que mencionar la propuesta presentada por la Comisión Asesora de Derecho Civil Balear de modificación de los arts. 53 y 84 de la Compilación de Derecho Civil balear (octubre 2014), por la que heredaba

39 Sobre esta cuestión, vid. Lamarca i Marqués, 2010.

40 Se refiere a la regulación de la sucesión ab intestato en Aragón la STC 41/2018, en relación con la sucesión a favor de la comunidad autónoma en defecto de parientes y cónyuge que ya se recogía en el derecho aragonés compilado con anterioridad a la Constitución (Compilación de 1967). Regulación que ahora está prevista en los arts. 535 y 536 del Código de Derecho Foral de Aragón.

41 Ahora se prevé en la Ley 304, apdo. 6, de la Ley Foral 21/2019, de 4 de abril, de modificación y actualización de la compilación del Derecho Civil Foral de Navarra o Fuero Nuevo. 
en último lugar la comunidad autónoma, siempre a beneficio de inventario. Esta propuesta también hacía un llamamiento al Gobierno balear para que dictara las normas reglamentarias de desarrollo y de actuación de los órganos administrativos en un plazo de seis meses. En la memoria justificativa de la propuesta presentada ya quedaba planteada la necesidad de una regulación más amplia y detallada de la sucesión intestada en las Illes Balears - regulación que todavía no ha llegado- y también se justificaba la competencia para realizar la modificación presentada. En este sentido, establecía que es general la consideración de que las comunidades autónomas con Derecho civil propio puedan regular esta materia, sin que ello conlleve ninguna infracción constitucional de ningún tipo. A mayor abundamiento, se citaba también la disposición final segunda de la Ley 33/2003, de 3 de noviembre, del Patrimonio de las Administraciones Públicas, que deja a salvo lo dispuesto en «los derechos civiles forales o especiales allí donde existan».

Coca Payeras se muestra crítico con el planteamiento de la reforma, ya que técnicamente los Consejos Insulares y los ayuntamientos se acercan más a la condición de beneficiarios que a la de herederos. De acuerdo con el art. 41 bis de la Ley 6/2001, de 11 de abril, de Patrimonio de la Comunidad Autónoma de las Illes Balears: la declaración de herederos se hará por la Administración autonómica, «en estrecha colaboración con los Consejos Insulares y Ayuntamientos». Después se les solicitará que hagan una propuesta de destinación de los bienes o derechos de la herencia y será el órgano competente en materia de patrimonio de la comunidad autónoma el que la valide y ejecute. El papel de los Consejos Insulares y ayuntamientos se limita considerablemente, desvirtuando, en palabras de Coca Payeras, la figura de los herederos ab intestato, quien se muestra favorable a que fuera la comunidad autónoma la heredera en el sentido del proyecto de ley citado anteriormente (2018: 133 y ss.).

Por lo que se refiere al contenido del artículo, la doctrina está de acuerdo en que se introduce la territorialidad en la aplicación de las normas y también destacan los problemas que pueden originarse en la práctica. En este sentido, Llodrá Grimalt se refiere a esta territorialidad que lo acerca a normas como el Reglamento (UE) n. ${ }^{\circ}$ 650/2012, de 4 de julio de 2011 (Llodrá Grimalt, 2018: 46-47). Desde un punto de vista crítico, Coca Payeras también se refiere a la expresión «isla del causante». Entiende este autor que lo que seguramente pretendió el legislador, pero que no ha quedado plasmado en la ley, era referirse «a la isla a la que pertenece el municipio en que tuvo su última residencia habitual el causante ${ }^{42} \gg$.

42 Vid. Coca Payeras (2018: 137). También se muestra crítico Jiménez Gallego al afirmar que parece haber cierta contradicción entre el criterio de la residencia y la vecindad 


\section{A MODO DE CONCLUSIONES}

De acuerdo con el título de este trabajo, se ha pretendido abordar la reforma del Derecho civil balear y su relación con la Constitución desde dos perspectivas diferentes. La primera, la posibilidad de que alguno de sus artículos chocara con el texto de la Constitución por lo que se refiere al ámbito competencial. En esta sede y una vez analizada la cuestión, se puede concluir, a la luz de los argumentos expuestos en diferentes apartados de este trabajo, que los visos de inconstitucionalidad no pueden prosperar, habiendo argumentos para su defensa. En el caso de la preceptiva autorización del cónyuge no titular en caso de actos de disposición sobre la vivienda familiar y su inconstitucionalidad por vulneración de normas mercantiles, tiene que descartarse al tratarse de una materia claramente civil que se enmarca en el art. 149.1.8. ${ }^{\mathrm{a}}$ $\mathrm{CE}$. Se refiere al cónyuge en general, por lo que, en principio, no chocaría con la Ley Concursal; y solo en caso de insolvencia podría plantearse, en su caso, como una ley especial en supuestos concretos, respetando los derechos civiles propios. En el caso del llamamiento a Consejos Insulares y ayuntamientos en la sucesión ab intestato, a falta de otros herederos, queda claramente salvada su constitucionalidad. Si se entendiera lo contrario se estaría vetando cualquier modificación de materias ya reguladas por el Derecho civil propio. Conclusión que se enmarca claramente dentro de la interpretación que hace el Tribunal Constitucional de la expresión "conservación, modificación y desarrollo por las Comunidades Autónomas de los derechos civiles, forales o especiales, allí donde existan» del art. 149.1.8. ${ }^{\mathrm{a}}$.

La segunda perspectiva, la reforma que se lleva a cabo, según afirma la propia Ley $7 / 2017$, de 3 de agosto, con la finalidad de protección del vínculo matrimonial, con la intención de proteger al cónyuge más desfavorecido constante matrimonio, atendidas todas las circunstancias concurrentes. En este caso, son cambios importantes que pretenden adaptar la regulación balear a la doctrina del Tribunal Constitucional sobre el matrimonio y la protección de la vivienda familiar.

Es una modificación amplia del Derecho civil balear, aunque por otra parte se reduce a determinados aspectos. En algunos casos ha habido modificación, como en la sucesión ab intestato. En otros, una regulación específica, añadiendo la compensación por razón del trabajo para la familia, sin olvidar la regla nueva en nuestra tradición: la autorización del cónyuge no titular en los actos de disposición de la vivienda familiar, lo que, de entrada, podría chocar

civil del causante para la aplicación de un determinado derecho civil (2018a: 26). 
con un régimen económico de separación de bienes como el balear. Medida por otra parte necesaria para proteger intereses superiores.

Se trata de una reforma que tendría que ser el inicio de un desarrollo del Derecho civil de las Illes Balears pausado y reflexivo y, sobre todo, adecuado a las necesidades actuales, dentro de las instituciones propias de nuestro derecho civil propio y en el marco establecido por nuestra Constitución; un derecho civil balear adaptado a las necesidades del siglo XXI.

\section{Bibliografía}

Álvarez Olalla, P. (2010). La incidencia de la Ley Concursal en los regímenes económicos matrimoniales de Derecho foral, a la luz del reparto competencial establecido en la Constitución. Derecho Privado y Constitución, 24, 67-107.

- (2016). La compensación por trabajo doméstico y el deber de contribución a las cargas del matrimonio en separación de bienes. Al hilo de la STS de 5 de mayo de 2016 y sus predecesoras. Revista Aranzadi Doctrinal Civil-Mercantil, 7 , 129-138.

(2017). El Tribunal Supremo concede el derecho a la compensación por trabajo doméstico en el régimen de separación de bienes, aunque la dedicación al hogar del cónyuge que la solicita no sea exclusiva, por haber colaborado en la empresa de su consorte. Comentario a la STS de 26 de abril de 2017 (RJ 2017\1720). Revista Doctrinal Aranzadi Civil-Mercantil, 8, 153-162.

Amat Llombart, P. (2017). La competencia legislativa en materia de derecho civil del artículo 149.1.8 a de la Constitución Española. Disfunciones en torno al derecho civil valenciano e interpretación del Tribunal Constitucional. Revista para el Análisis del Derecho (InDret), 4, 1-32.

Arroyo Amayuelas, E. (2010). Competència autonómica, competencia entre ordenaments jurídics i codificació del Dret civil català: un balanç. Revista de Dret Històric Català, 10, 167-213.

Bercovitz Rodríguez-Cano, R. (2018). El requisito de la conexión para el desarrollo de los derechos civiles forales o especiales. Revista Doctrinal Aranzadi Civil-Mercantil, 7, 19-26.

Berrocal Lanzarot, A. I. (2017). Efectos patrimoniales en el régimen de separación de bienes. Revista Crítica de Derecho Inmobiliario, 763 (93), 2606-2645.

Bosch Capdevila, E. (2010). L'evolució del règim de separació de béns en el Dret Civil de Catalunya: la compensació económica per raó del treball. Revista Jurídica de Catalunya, 4 (109), 1075-1098.

Cardona Guasch, O. (2018). Comentario a las modificaciones operadas en el Libro III de la Compilación por la Ley 7/2017, de 3 de agosto. Boletín de la Real Academia de Jurisprudencia y Legislación de las Illes Balears, 19, 167-184. 
Carlón Ruiz, M. (2015). Comentario a la Disposición final trigésimo segunda de la Ley Concursal. En A. Rojo y E. Beltrán (dirs.). Comentarios a la Ley Concursal. Madrid: Civitas.

Coca Payeras, M. (2018). Notas sobre la regulación de la sucesión intestada en la Compilación de Derecho Civil de las Islas Baleares, instaurada por la Ley 7/2017. Boletín de la Real Academia de Jurisprudencia y Legislación de las Illes Balears, 19, 121-144.

Costas Rodal, L. (2009). Comentario al artículo 1320 Código civil. En R. Bercovitz Rodríguez-Cano (dir.). Comentarios al Código Civil. Pamplona: Aranzadi.

De Verda y Beamonte, J. R. (2017). ¿Qué es lo que queda del Derecho civil valenciano en materia de familia? Derecho Privado y Constitución, 31, 111-162. Disponible en: https://doi.org/10.18042/cepc/dpc.31.03.

Domínguez Martínez, P. (2012). La protección de la vivienda familiar en situación de normal matrimonio en el ordenamiento jurídico civil. Revista Doctrinal Aranzadi Civil-Mercantil, 4 (2), 73-90.

Egusquiza Balmaseda, M. A. (2018). Conexión institucional necesaria: «desarrollo» de los derechos civiles propios en la última jurisprudencia del Tribunal Constitucional. Derecho Privado y Constitución, 33, 47-78. Disponible en: https://doi. org/10.18042/cepc/dpc.33.02.

Erdozáin López, C. (2007). La disposición de derechos sobre la vivienda habitual según la reciente jurisprudencia. Revista Doctrinal Aranzadi Civil-Mercantil, 2, 79-98.

Ferrer Vanrell, M. P. (2001). La problemática de la aplicabilidad del artículo 1.320 del Código civil a los ordenamientos civiles territoriales (a la luz de la sentencia de 3 de septiembre de 1998 de TSJB). Revista Crítica de Derecho Inmobiliario, 665 (77), 1079-1136.

— (2018). Las fuentes del Derecho Civil Balear y su aplicación tras la reforma por Ley 7/2017, de 3 de agosto. Boletin de la Real Academia de Jurisprudencia y Legislación de las Illes Balears, 19, 9-46.

Galicia Aizpurua, G. y Castellanos Cámara, S. (2018). Últimas reformas y propuestas de reforma en derecho de sucesiones. Revista Doctrinal Aranzadi Civil-Mercantil, 3, 27-70.

García Rubio, M. P. (2017). Presente y futuro del Derecho civil español en clave de competencias normativas. Revista de Derecho Civil, 3 (4), 1-33. Disponible en: https://bit.ly/2H0VTzg.

Jiménez Gallego, C. (2018a). La reforma de la Compilación de Derecho Civil de Baleares por la Ley 7/2017. En Seminarios y conferencias del curso 2017-18 del Colegio Notarial de las Illes Balears (pp. 9-38).

— (2018b). Los derechos sucesorios del cónyuge viudo tras la Ley 7/2017, de reforma de la Compilación. Boletín de la Real Academia de Jurisprudencia y Legislación de las Illes Balears, 19, 89-112.

Lamarca I Marquès, A. (2010). Successió intestada a Catalunya. De la Compilació al Codi Civil i els cinquanta anys entre dues lleis (1936-1987). Revista Jurídica de Catalunya, 4 (109), 1169-1214. 
Llodrá Grimalt, F. (2011). La sucesión intestada en Baleares. En M. C. Gete-Alonso (dir.) y J. Solé (coord.). Tratado de Derecho de Sucesiones. Tomo II. Navarra: Civitas.

- (2017a). Observaciones en relación con la nota de 11.10.2017 de la Dirección General de relaciones con las Comunidades Autónomas, relativa a la Ley Balear 7/2017. Primera parte [trabajo inédito].

- (2017b). Observaciones en relación con la Nota de 11.10.2017 de la DG de Relaciones con las Comunidades Autónomas, relativa a la Ley Balear 7/2017. Segunda parte [trabajo inédito].

(2018). Anàlisi de la Llei 7/2017, de 3 d'agost, per la qual es modifica la Compilació de Dret Civil de les Illes Balears i del seuprocés. Revista Jurídica de les Illes Balears, 16, 37-68.

Martín Meléndez, M. T. (2014). Estudio jurídico civil de la explotación agraria de titularidad compartida y de la compensación por colaboración efectiva en la explotación agraria desde la perspectiva del régimen económico matrimonial. Anuario de Derecho Civil, 67 (2), 517-597.

Masot Miquel, M. (2016). Algunas consideraciones sobre la compensación económica del trabajo para la familia y su incidencia en el Derecho Civil de las Illes Balears. Boletín de la Real Academia de Legislación y Jurisprudencia de las Illes Balears, 17, 701-732.

_ (2018). El régimen económico del matrimonio en nuestras islas tras las apresuradas reformas de la Ley 7/2017, de 3 de agosto. Boletín de la Real Academia de Legislación y Jurisprudencia de las Illes Balears, 19, 69-88.

Moreno Flórez, R. M. (2018). El trabajo para la casa en el régimen de separación de bienes. ¿Exclusivo, o compatible con una actividad remunerada? Revista de Derecho Civil, 4 (5), 233-279. Disponible en: https://bit.ly/2H0lylo.

Munar Bernat, P. (2014). Disposición de la vivienda familiar y donaciones entre cónyuges. Algunas consideraciones críticas sobre el Anteproyecto de Ley de Régimen Patrimonial del Matrimonio de 2013. Boletín de la Real Academia de Legislación y Jurisprudencia de las Illes Balears, 15, 189-277.

Palao Gil, F. J. (2017). We Cannot Turn the clock back: rigidez constitucional, formalismo jurídico y derecho civil valenciano. Derecho Privado y Constitución, 31, 163-216. Disponible en: https://doi.org/10.18042/cepc/dpc.31.04.

Tur Faúndez, N. (2011). La compensación económica por el trabajo para la familia en el Derecho Civil Balear (A propósito de la sentencia del TSJIB 2/2010, de 24 de marzo). Revista Jurídica de les Illes Balears, 9, 117-124.

Verdera Izquierdo, B. (2018). Panorama actual de la compensación económica por trabajo para la familia en Baleares. Revista de Derecho Civil, 4 (5), 1-51. Disponible en: https://bit.ly/2WvISUO. 